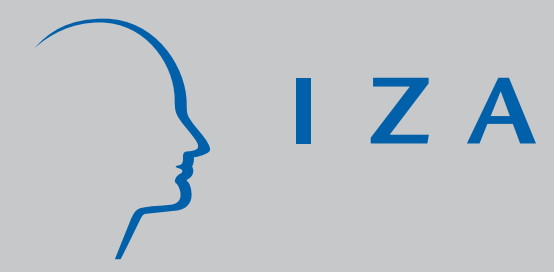

IZA DP No. 812

German Works Councils in the Production Process

\author{
J ohn T. Addison \\ Thorsten Schank \\ Claus Schnabel \\ J oachim Wagner \\ J une 2003
}




\title{
German Works Councils in the Production Process
}

\author{
John T. Addison \\ University of South Carolina and IZA Bonn \\ Thorsten Schank \\ University of Erlangen-Nuremberg \\ Claus Schnabel \\ University of Erlangen-Nuremberg \\ Joachim Wagner \\ University of Lueneburg, HWWA and IZA Bonn
}

Discussion Paper No. 812
June 2003

IZA

P.O. Box 7240

D-53072 Bonn

Germany

Tel.: +49-228-3894-0

Fax: +49-228-3894-210

Email: iza@iza.org

\begin{abstract}
This Discussion Paper is issued within the framework of IZA's research area Welfare State and Labor Market. Any opinions expressed here are those of the author(s) and not those of the institute. Research disseminated by IZA may include views on policy, but the institute itself takes no institutional policy positions.
\end{abstract}

The Institute for the Study of Labor (IZA) in Bonn is a local and virtual international research center and a place of communication between science, politics and business. IZA is an independent, nonprofit limited liability company (Gesellschaft mit beschränkter Haftung) supported by Deutsche Post World Net. The center is associated with the University of Bonn and offers a stimulating research environment through its research networks, research support, and visitors and doctoral programs. IZA engages in (i) original and internationally competitive research in all fields of labor economics, (ii) development of policy concepts, and (iii) dissemination of research results and concepts to the interested public. The current research program deals with (1) mobility and flexibility of labor, (2) internationalization of labor markets, (3) welfare state and labor market, (4) labor markets in transition countries, (5) the future of labor, (6) evaluation of labor market policies and projects and (7) general labor economics.

IZA Discussion Papers often represent preliminary work and are circulated to encourage discussion. Citation of such a paper should account for its provisional character. A revised version may be available on the IZA website (www.iza.org) or directly from the author. 
IZA Discussion Paper No. 812

June 2003

\section{ABSTRACT}

\section{German Works Councils in the Production Process*}

In a sharp break with past German research, some recent estimates have suggested that plants with work councils have 25 to 30 per cent higher productivity than their works-councilfree counterparts. Such findings can only serve to buttress the strong theoretical and policy interest in the German institution, not least in an environment of union decline. In the present paper, we estimate the effects of works councils on productivity, 1997-2000, using a nationally representative German data set. We recoup the works council effect by estimating translog production functions, stochastic frontier production functions, and a model in first differences. Once we focus on a core sample of establishments with 21 to 100 employees in which the powers of the works council are a datum, it emerges that the positive productivity differential is a chimera. By the same token, neither is the effect negative. This result is important in its own right given the sharply opposing findings of past empirical research and the partisan positions these have helped sustain.

JEL Classification: J50

Keywords: $\quad$ works councils, production functions, panel data, Germany

Corresponding author:

Joachim Wagner

Institute of Economics

University of Lueneburg

21332 Lueneburg

Germany

Email: wagner@uni-lueneburg.de

\footnotetext{
* This paper uses data from the IAB Establishment panel, which is financially supported by the European Social Fund. Addison was a guest of the IAB during the completion of this paper. He wishes to thank the IAB for its generous support and excellent research environment.
} 


\section{Introduction}

These are interesting times for German works councils. In the first place, recent changes to national legislation - via the 2001 Works Constitution Act - have made it easier to establish this form of workplace representation, while at the same time enhancing the competence or powers of the entity (see Addison, Bellmann, Schnabel, and Wagner, 2003). In the second place, with the German system clearly in mind, the European Union (EU) has just legislated minimum standards in respect of national systems for informing and consulting employees in undertakings (establishments) with a minimum of 50 (20) employees (Official Journal, 2002). In both cases, the stated reasons for strengthening worker rights include an efficiency rationale. As a practical matter, however, rather little is known of the effects of information, consultation, and participation on firm/establishment performance. (This deficit also characterizes the high performance work practice literature more generally.) Indeed, at the time the changes to the German legislation were mooted, the Codetermination Commission set up to review the operation of the existing codetermination machinery and to make recommendations for its improvement, concluded that the available econometric evidence was "equivocal." Specifically, it noted that "quantitative studies that ascribe (usually weak) positive effects to codetermination for specific indicators of performance and periods of time must be offset against others that find (in most cases also weak) negative effects for other or the same indicators and periods. Statistically significant results are seldom and their explanatory power value seems limited in the light of the results of other studies with which they cannot easily be reconciled (Kommission Mitbestimmung, 1998; English summary, p. 6). ${ }^{1}$

Although the Commission's interpretation of the empirical literature on works council effects is idiosyncratic - as we shall see, the empirical literature at that time at least was certainly less fragmented and its thrust more negative on codetermination than it suggested there can be little doubt that the paucity of research has not proved a barrier to policy innovation, and may even have facilitated reform. Be that as it may, with the EU legislation now in place, there is now something of a scramble to review past findings and conduct new research into the economic impact of participative institutions. This is partly because the design of the institutions of information and consultation, as well as the employment size thresholds that are to apply, is left up to the member states. The reality of legislative review the process whereby amendments are made to all such EU legislation - has of course also played a role. 
The present paper is offered as a contribution to this ongoing debate on employee involvement. The focus is on Germany and the works council institution. In a sharp break with the past literature, several recent empirical studies for Germany have suggested that establishments with works councils have much higher productivity than their works councilfree counterparts. Past research typically pointed to lower productivity in works council settings, and indeed to a variety of other unfavorable outcomes as well. But, unlike the most recent studies, the earlier productivity analyses did not use formal production function tests per se because of missing data on capital stock, while their findings for other performance outcomes were clouded by the often subjective nature of the indicators (e.g. managerial perceptions of financial performance). Using output data, and a variety of functional forms, we here investigate the impact of the works council on establishment productivity. Specifically, we provide works-council-in-the-production-function tests, derive es timates of relative plant efficiency using a frontier production approach, and also look at productivity growth in the two workplace regimes using first difference techniques. The goal is to determine whether the recent optimism with respect to works council impact is warranted at a time when the EU has mandated domestic works council-like structures in member states (as well as international works councils in multinational corporations) and Germany has sought to increase the penetration and reach of works councils.

The plan of the paper is as follows. Section II offers some theoretical conjectures on why works councils may be viewed as the exemplar of collective voice. Section III provides a concise review of the previous empirical literature, so as to set the scene for our own inquiry and specifications. Section IV provides detail on the estimating framework, and section V describes the unique, nationally representative data set used here. Our detailed findings are reported in section VI. A brief interpretative section concludes.

\section{Theoretical Backdrop}

The model of collective voice was designed to apply to the trade union (see Freeman, 1976; Freeman and Medoff, 1984). Previously, justification for union-induced improvements in performance was linked to notions of X-inefficiency and shock effects. The new approach emphasized the communal nature of working conditions, which affect all workers in the establishment and create a public goods problem of preference revelation. By collecting information on the preferences of all workers, unions may enable firms to choose a more efficient mix of wage and personnel policies. Collective voice not only provides a direct channel of communication between workers and management but also a way of expressing 
dissatisfaction other than through quits. As a result of both forces, labor turnover should fall, permitting lower hiring and training costs and stimulating firm-specific human capital investments. Increases in efficiency may result. A further potential efficiency gain is implied by another public goods aspect of the workplace, namely, significant complementarities in effort input. Without some form of collective organization, so the argument runs, the incentive of the individual to take into account the effect of his actions on others may be too small - just as with preference revelation - permitting scope for collective action to improve matters. For the public goods argument to have traction, however, there must be costs attaching to the use of external markets and, further, the workplace must be subject to unforeseen shocks. The presence of such factors means that the firm will have a continuing need for information from workers.

This collective voice model is singularly open ended. First, as acknowledged by its proponents - and quite apart from the recognition that unions are also monopolies - much hinges on management's response to collective bargaining and on the union's response to any reorganization of the workplace. In short, the collective voice model is actually a collective voice/institutional response model. In this sense, the circumstances of time and place may play an important role; in particular, the effect of the union may vary though time with the maturation of the collective bargaining relation, changes in the legal environment, and so on. Second, the efficiency benefits attributed to unionism are largely those ascribed to the governance apparatus of the internal labor market and efficient but incomplete contracting models (e.g. Williamson, Wachter, and Harris, 1975). Since such models almost never mention unions, there is a very real issue of whether the advantages of collective voice are obtainable without the union entity, through other voluntary institutions.

Some recent developments have suggested that the market may fail to produce efficient voluntary arrangements after all - echoing the argument made earlier that even with unions some legal protection of collective voice is needed (Freeman, 1976, p. 364). For our purposes the most relevant analysis is Freeman and Lazear's (1995) purpose-built works council model. ${ }^{2}$ In this model, the joint surplus of the firm increases as one moves cumulatively from information exchange through consultation to participation. Among other things, information rights can help verify management claims about the state of nature, rendering them credible to the workforce and avoiding costly disputes - even precipitating the failure of the enterprise. Consultation for its part allows new solutions to production and other problems by reason of the non-overlapping information sets of the two sides and the creativity of discussion. Finally, participation or codetermination rights increase the joint surplus by 
providing workers with more job security and encouraging them to take a longer-run view of the firm and its prospects.

So far so good because German works councils are distinguished not only by the reach of the information exchange and consultation machinery but also, and more importantly, by their codetermination (and consent) rights. ${ }^{3}$ Unless somehow constrained, however, these rights give rise to the self-same bargaining problem attaching to all employee involvement models. Freeman and Lazear squarely confront this problem (cf. Levine and Tyson, 1990), arguing that the workers' share in the joint surplus grows with that surplus while that of capital declines both relatively and absolutely. The workers' share rises because knowledge and involvement are power, so that the same factors that cause the surplus to rise also cause profitability to fall. It follows that workers will demand too much power/involvement because their share will continue to rise after the joint surplus has peaked. Similarly, employers will either oppose works councils or vest them with too little power because profits decline even as the surplus is increasing.

Against this backdrop, Freeman and Lazear see the German institution as attractive in two respects. First, the German Betriebsrat can not strike (under the so-called peace obligation'). Second, neither can it formally engage in bargaining over wages and other conditions of employment unless authorized to do so under the relevant industry-level or regional collective bargaining agreement. In this respect, the authors speak of a potential 'decoupling' of the factors that determine the size of the surplus from those that determine its distribution. Left open is whether or not there is a sufficient decoupling in practice. At one level, there is presumably the requirement that the works council must function within a dual system, that is, be embedded in a wider collective bargaining framework that exerts some control over the workplace. Beyond that, however, there is the unsettled question of the nature of the works council, namely, works council power and/or 'type' since we know that bilateral plant agreements negotiated by the works council have often ranged well beyond the terms prescribed by the law (Müller-Jentsch, 1995). Needless to say, it has proved easier to operationalize the formal collective barga ining framework than to accommodate differences in works councils. A further complication here is that the rights of the works council under the German law are not a datum but are instead increasing in establishment size.

Even if the works council is an exemplary collective voice institution, therefore, theory does not provide an unambiguous answer as to its consequences for efficiency. And, as we have hinted, the empirical evidence is also mixed. The result provides an inauspicious background to the pronounced policy activism of recent years. Interestingly, however, 
although it came too late to inform debate and shape these policies, the most recent empirical research has contained some of the most favorable evaluations of works council impact.

\section{The Empirical Literature}

Econometric research into the impact of German works councils on firm performance dates from the mid-to-late 1980s. It follows three main stages or phases, beginning with studies based on small samples of plants through analyses of much larger data sets for manufacturing covering a single region or sector to work on truly nationally representative samples of establishments (see Addison, Schnabel, and Wagner, 2003). Studies within the first phase contain a wide range of performance outcomes: objective and subjective measures of profits (see, for example, FitzRoy and Kraft, 1985, Addison, Kraft, and Wagner, 1993; Addison and Wagner, 1997); product innovation and R\&D (see FitzRoy and Kraft, 1990, Addison and Wagner, 1997; Schnabel and Wagner, 1994); investment in physical capital, (Addison, Kraft, and Wagner, 1993), and (excessive) quits (Kraft, 1986). And, via a production function framework, two of the studies also estimate works council effects on total factor productivity and labor productivity (see, respectively, FitzRoy and Kraft, 1987; Addison, Kraft, and Wagner, 1993). These early studies do not lack rigor, and on occasion instrument works council presence or otherwise seek to account for differences in 'type' of works council (see FitzRoy and Kraft, 1987, 1990; Addison and Wagner, 1997). But they all suffer from the problems associated with small sample size.

Studies of the second phase have a basis in two main data sets: the Hannover Firm Panel and the NIFA-Panel. The former is a stratified random sample of all manufacturing plants with at least 5 employees in the German state of Lower Saxony, while the latter covers all establishments in the German machine tool industry. They are also panels, covering 1994 98 and 1989-99, respective ly. Studies using these two data sets thus have the clear advantage of large samples of firms - typically exceeding 900 units, as compared with under 100 in the case of first phase studies - with detailed plant and industry controls. By the same token, however, the two panels lack information on certain key variables, including capital. Despite the omitted variables problem, nearly all studies consider works council effects on value added per employee (see, inter al., Addison, Schnabel, and Wagner, 2001; Hübler and Jirjahn, 2001; Jirjahn, 2002; Frick, 2001). Another problem is that the data sets either do not have information on union membership at the establishment (the NIFA Panel) or lack reliable information on workplace union density (the Hannover Firm Panel). But the studies make up for this by exploiting other information on collective bargaining, namely, being covered by a 
collective agreement at industry or regional level. And in one case, an explicit test of the Freeman-Lazear argument - encountered in Section II - is offered (see Hübler and Jirjahn, 2001). Overt advantages of the new data sets other than the greatly expanded number of plants include their panel nature (although the 'persistence' of works councils ultimately means that analysts use stacked cross sections rather than panel estimation proper), richer information on employee involvement/high performance work practices, and, in the case of the NIFA panel actual information on works council type and degree of works council involvement, at least as assessed by the manager respondent (see Dilger, 2002).

Studies of the third phase work with data from a truly nationally representative source: the Establishment Panel of the Institute for Labor Market Research (Institut für Arbeitsmarktund Berufsforschung/IAB) of the Federal Labor Office (Bundesanstalt für Arbeit). This employment-based IAB Panel is used in the present empirical inquiry and is described in section V. Because it contains a measure of the capital stock (albeit indirect), the ne w data set can be used to provide works-council-in-the production-function or analogous estimates of labor productivity (see Frick, 2002a, 2002b; Wolf and Zwick, 2002; Schank, Schnabel and Wagner, 2002). As is the case for the other large-scale data sets, however, the ability to fully exploit the longitudinal nature of this panel is constrained by the lack of change in works council status over its life to date (1993-2001).

As one moves progressively through the various stages of research, some pronounced changes in works council effect are detected. The findings from the first phase are frankly pessimistic with respect to the ability of representative participation to improve establishment performance. Only one study actually reports a beneficial impact - namely, Schnabel and Wagner's (1994) finding of a positive and weakly statistically significant association between works council presence and R\&D intensity - while others report some strongly negative effects. The latter studies include all those by FitzRoy and Kraft (1985, 1987, 1990), quite irrespective of the outcome indicator examined. These authors offer a management pressure/competence interpretation of the evidence, arguing that efficient managers are able to elicit greater effort from their workforces and are duly rewarded with higher salaries and profits. They are also able to institute adequate systems of communication and decisionmaking without the paraphernalia of a works council, and partly by paying higher wages. Other negative results from oher studies include investment (Addison, Kraft, and Wagner, 1993) and the seeming failure of collective voice (via the works council) as compared with individual voice to significantly lower excess quits (Kraft, 1986) - the latter result being perhaps the unkindest cut of all. 
On the other hand, findings from the second phase are rather more optimistic. The general effect of works councils across the range of outcome indicators is no longer adverse with the exception of profitability (which is not an unambiguous indicator because the impact may simply be a transfer). The 'average' works council effect would furthermore appear to obscure some systematic differences by establishment size, collective bargaining coverage, and employee involvement mechanism. Thus, if there is the suggestion that small establishments have been disadvantaged by works councils, there is also the indication that larger plants might need to invent something akin to works councils in the absence of their being mandated under law (Addison, Schnabel and Wagner, 2001). For its part, collective bargaining outside the plant may assist in decoupling distribution from production issues and help focus the works council on the latter, with the indication of higher labor productivity in works council plants where these are covered by a collective agreement at industry/regional level (Hübler and Jirjahn, 2001). And other forms of employee involvement might be pro productive in works council regimes allowing otherwise negative results (such as on profitability) to be reversed (see, for example, Dilger, 2002).

Arguably, the third phase is even yet more optimistic about the effect of works councils on firm performance, with the two earliest production function studies pointing to 25 to 30 per cent higher labor productivity in work council regimes (Frick, 2002a, 2002b). These values come from estimates that do not control for factors such as unobserved plant heterogeneity. Nevertheless, support for rather substantive albeit less flamboyant works council effects are available in specifications that at least in part do so (viz. Wolf and Zwick, 2002).

Are we therefore to conclude that more recent research has either contradicted the findings of the first phase - or, equivalently, that there has been a sea change in works council impact as a result of a maturation in German industrial relations practice, as some research outside of economics has suggested (Kotthoff, 1994)? We must be cautious in reaching any such conclusion for a number of reasons. First, and most obviously, the most recent research is not quite as cut and dried as we have suggested. Thus, in estimating a fixed effects frontier production function separately for works council and works-council-free regimes in the IAB Panel and then comparing technical efficiencies of median plants in the two regimes, Schank, Schnabel, and Wagner (2002) find no evidence that works council plants are more efficient than their counterparts without councils (i.e. the confidence intervals of the reported technical efficiency estimates for the two plants types overlap). Furthermore, separate research pointing 
to higher rates of plant closings among the firmament of works council establishments may hint at survivability bias in cross section (see Addison, Bellmann, and Kölling, 2004).

Second, one lesson of the second-phase literature is that works council effects may differ markedly by establishment size. It seems to be no less important to recognize this sensitivity in the production function estimates as well. In particular, it makes sense to look at results for a sample of establishments in which the powers of the works council are a datum. As a matter of fact, works council power is a stepped function of employment and this is likely to be reflected in works council frequency as a result of worker choice. Given the difficulty of identifying a works council equation (in a system of equations or in otherwise instrumenting the entity), one natural way is to configure the sample for a range of employment over which the council's competence does not vary.

Third, and relatedly, since the IAB Establishment Panel does not contain information on works council type, there is the problem that above (below) some employment threshold virtually all (no) plants have works councils. It is not clear how estimates from the IAB Panel are sensitive to or otherwise reflect this problem. One solution is to estimate the works council effect over a sample of firms with 21 to 100 employees where works councils are found in roughly half the sample. No less important, the powers of the works council are also a datum over this employment range.

Fourth, although we have not mentioned it thus far, studies presenting the most optimistic results from the IAB Establishment Panel also point to sensitivity to sector. It would be interesting to discover the sensitivity of production function estimates to disaggregation along a number of other dimensions. Finally, because there are no formal estimates of works council impact using panel methods, there is some virtue in estimating a first difference model as well.

In short, lessons learnt from earlier stages of works council research should inform estimation using the IAB Establishment Panel. The present empirical exercise is motivated precisely by this concern.

\section{The Production Function Framework}

In this section, we present the functional framework used in our empirical inquiry. A straightforward way to characterize the technology of a firm is the production function, defined as the maximum output of $\mathrm{y}$ attainable with a given set of inputs $\mathrm{x}$ and a given technology. We will use two production function specifications in our empirical analysis: the more general translog and its nested Cobb-Douglas specification. 
The translog production function - introduced by Christensen, Jorgenson and Lau (1971, 1973) - belongs to the family of flexible functional forms. These are local approximations of an arbitrary, twice continuously differentiable production function. The translog function is defined as follows:

$\ln y=\beta_{0}+\sum_{i=1}^{n} \beta_{i} \ln x_{i}+\frac{1}{2} \sum_{i=1}^{n} \sum_{j=1}^{n} \beta_{i j} \ln x_{i} \ln x_{j}$.

with $\beta_{i j}=\beta_{j i}$.

Although this formulation is linear-in-parameters and conceptually simple, it does not impose any restrictions on returns-to-scale and the substitution elasticities. In our empirical investigations, we use labour (N) and capital (K) as inputs. Hence, the general formulation in equation (1) can be written as:

$\ln y=\beta_{0}+\beta_{1} \ln N+\beta_{2} \ln K+\beta_{11} \frac{\ln ^{2} N}{2}+\beta_{22} \frac{\ln ^{2} K}{2}+\beta_{12} \ln N \ln K+\gamma Z+\varepsilon$,

where the vector $Z$ captures additional control variables and $\varepsilon$ is an error term. If we view the translog as an approximation of the underlying production technology, then the higher than second-order terms will be absorbed in the error term. Since these terms depend on $\mathrm{x}$ (in our case $N$ and $K$ ), the parameter estimates will be biased and inconsistent. Hence, we shall follow a strategy common to many empirical investigations in assuming that the translog is not an approximation but rather an exact functional relationship. ${ }^{4}$ This allows us to consider the disturbance $\varepsilon$ in equation (2) as a white noise error term, comprising random variation of (a) the technology of the production unit, (b) the environment of each firm, (c) the behavior of the production unit, and (d) observational errors (measurement or aggregation errors).

The output elasticities with respect to employment and capital - namely, the percentage change in output following one per cent change in employment and capital, respectively - are given by the expressions:

$$
\begin{aligned}
& \frac{\partial \ln Y}{\partial \ln N}=\beta_{1}+\beta_{11} \ln N+\beta_{12} \ln K \\
& \frac{\partial \ln Y}{\partial \ln K}=\beta_{2}+\beta_{22} \ln K+\beta_{12} \ln N .
\end{aligned}
$$

If we insert the coefficient estimates and values of the sample means for $\ln N$ and $\ln K$, we obtain estimates of the respective elasticities. Note that constant returns-to-scale impose the following two restrictions on the parameters: (a) the coefficients on the logarithm of employment and the logarithm of capital sum to unity $\left(\beta_{1}+\beta_{2}=1\right)$, and (b) the sum of the 
coefficients on the squared logarithms of output and capital and of the interaction term for both logarithms is zero $\left(\beta_{11}+\beta_{22}+\beta_{12}=0\right)$.

The first parametric production function estimated is the Cobb-Douglas type specification. Although returns-to-scale are still allowed to be below, equal to or above unity, the elasticity of substitution is restricted to one. This model is obtained by restricting the coefficients $\beta_{11}, \beta_{22}, \beta_{12}$ to be zero. Accordingly, the hypothesis that the specification of a Cobb-Douglas technology is appropriate can be examined by testing the joint significance of these three coefficients.

Although a production function defines the maximum output obtainable with a given set of inputs, not all firms may combine labour and capital in an optimal manner. In other words, firms may be technically inefficient because they achieve less output than is feasible. But OLS estimation of production functions attributes all variation in a firm's performance that is not explained by the independent variables to statistical noise, irrespective of whether or not this variation is under a firm's control. Production function estimates are then obtained by simply averaging this unobserved firm heterogeneity. As a result, we obtain averages rather than frontiers. Expressed differently, the estimated functions pass through the data rather than surrounding the data.

By contrast, the stochastic production frontier approach, developed by Aigner, Lovell, and Schmidt (1977) and Meeusen and van den Broeck (1977), assembles production frontiers and measures a firm's efficiency relative to the constructed frontier. In order to distinguish unobserved random variation from unobserved inefficiency, the error term comprises two components:

$\varepsilon_{i t}=v_{i t}-u_{i}$.

Note that equation (5) introduces a firm index $i$ and a time index $t$, both of which subscripts have been omitted thus far for expositional convenience. Now $v_{i t}$ captures statistical white noise and $u_{i}$ depicts technical inefficiency, which is assumed to be non-negative and timeinvariant.

Defining $\beta_{i}=\beta_{0}-u_{i}$, equation (2) may be rewritten:

$\ln y=\beta_{i}+\beta_{1} \ln N+\beta_{2} \ln K+\beta_{11} \frac{\ln ^{2} N}{2}+\beta_{22} \frac{\ln ^{2} K}{2}+\beta_{12} \ln N \ln K+\gamma Z+v_{i t}$,

which can be estimated by a fixed-effects regression. Following Schmidt and Sickles (1984), we shall normalize the efficienc y of the most efficient plant as 100 per cent. Hence, estimates 
of the technical inefficiencies of the other plants are obtained as intercept shifts relative to the most efficient plant:

$\hat{u}_{i}=\max _{j} \beta_{j}-\beta_{i}$.

Since equation (6) is specified in logarithms, producer-specific estimates of technical efficiencies, defined as the ratio of a plant's actual output to its maximum attainable output, are then given by:

$T E_{i}=\exp \left\{-\hat{u}_{i}\right\}$

which is bounded by zero and one. In a second stage, we shall compare the median technical efficiency of plants having a works council with the median technical efficiency of plants where no works council is present.

There are estimators other than fixed effects available to the investigator, ramely, random effects and maximum likelihood. However, the great virtue of the present estimator is that the technical efficiencies are not required to be uncorrelated with the regressors. Nor for that matter are any distributional assumptions required for the $u_{i}$. The downside of estimating the stochastic production frontier by fixed effects is that time-invariant firm characteristics reappear in the estimated fixed effects (in addition to technical inefficiency), and therefore influence the estimated inefficiencies. However, in the present context, this could only have an impact on our findings were these time-invariant firm characteristics to be correlated with the existence of a works council.

\section{The Data Set and Estimation Strategies}

Data .

Our data are taken from the IAB Establishment Panel of the Institute for Employment Research of the Federal Labor Office. Each year since 1993 (1996), this panel has surveyed several thousand establishments from all sectors of the economy in western (eastern) Germany. It is based on a stratified random sample - strata for 16 industries and 10 size classes - from the population of all establishments with at least one employee covered by social insurance. To correct for panel mortality, exits, and newly-founded units, the data are

augmented regularly, yielding an unbalanced panel. Participation of establishments is voluntary, but the response rates (which exceed 70 per cent) are high compared with other non- official German firm panel studies. Data are collected in personal interviews with the owners or senior managers of the establishments by professional interviewers. The panel is created to serve the needs of the Federal Labor Office, and so its focus is on employment- 
related matters. Note that the IAB panel is the only German nationally representative longitudinal sample of establishments that can be used to investigate the impact of works councils. Details regarding the IAB panel (including information on the questionnaire(s) and how to access the data) are given in Kölling (2000).

Our inquiry uses information for the years 1997 to 2000. Note that some of the information related to year $t$ is asked for in the survey conducted in the following year - an example being total sales in year $t$ - so we actually use data from five surveys. The early years of the panel were excluded because one focus of the present exercise is to effect comparisons between western and eastern Germany. As noted, establishments in eastern Germany were only surveyed from 1996 onward. And we do not employ data for 1996 because we use information on replacement investment to measure capital input, and this question was asked for the first time only in 1997.

We shall consider establishments across all sectors (but see below) and establishments from the two broad sectors of manufacturing and services. Because output is measured differently for establishments from banking and insurance, and for public sector establishments, these industries are excluded here. Furthermore, we excluded establishments in agriculture, forestry, and fisheries for two reasons: (a) the production process in this branch differs from that in other sectors, and (b) works councils are present in just three percent of all such establishments, as compared with twelve percent in the rest of the economy.

According to the German Works Constitution Act, works councils can be elected in all establishments with at least five employees. We shall therefore exclude all establishments with less than five employees in at least one year. But note that, consistent with the terms of the legislation, part-time workers and apprentices are counted in full in this total. The empirical models are estimated for all establishments, and separately for establishments with 21 to 100 employees. It will be recalled that the reasons for this strategy are twofold. First of all, works council rights tend to increase with firm size, but are constant within certain size intervals. Looking at firms from one such size class is a way to control for hete rogeneity of works councils. Second of all, although works councils are rare among very small establishments, establishments without a works council are rare in higher size classes (see, for example, Addison, Bellmann, Schnabel, and Wagner, 2002). On the ther hand, as can be seen from the unweighted figures in the lower panel of Table 1, for the size interval of 21 to 100 employees one-third of the establishments in our sample have a works council. Accordingly, this category is especially well suited to in vestigate works council effects. Note that according to the weighted figures reported in the upper panel of the table, works councils 
are more commonly encountered in manufacturing than services in western Germany whereas the opposite is true for eastern Germany.

[Table 1 near here]

\section{Estimation Strategy.}

In investigating the impact of works councils on establishment productivity, we apply three different estimation strategies, each based on one variant of the production function approach. These strategies use different definitions of some of the variables and therefore need to be discussed here. Beginning with our first approach, this uses pooled data for 1997 to 2000 to estimate translog production functions (discussed in section IV) by OLS. As was noted earlier, the translog specification is preferred here because it is the least restrictive production function, nesting Cobb-Douglas and other specifications (such as CES).

The endogenous variable, output, is measured by the volume of total sales of the establishment in a year. Ideally, output should be measured in physical units, but this information is not available in the IAB panel. In recent studies by Frick (2002b) and Wolf and Zwick (2002) using the same panel, value added (computed by subtracting the cos ts of materials from sales) is used as a measure of output. Although conceptually superior to total sales, this measure suffers from two shortcomings. First, the interviewees are asked to estimate the percentage share of total sales represented by materiak cost, and (1 minus) this share is used in conjunction with sales volume to yield the value added measure. We consider the results of this exercise to be little more than "informed guesstimates" of an unknown quality, ${ }^{5}$ whereas the figures for total sales are numbers well known to an owner or manager of an establishment. Second, interviewees often fail to answer the enabling 'cost share' question so that use of value added involves a large reduction in the number of observations. For example, the sample of all establishments with five or more employees would be reduced by 20 per cent (from 11,464 to 9,361 units) if we used value added. Given that log total sales and $\log$ value added (constructed as above) are highly positively correlated for the establishments in the IAB panel and for all the sub-samples considered here, ${ }^{6}$ we opted not to lose a large part of the sample and work with sales volume as our proxy for output.

Turning to the exogenous variables, a crucial argument is of course the presence or otherwise of a works council. But although information on most variables is collected for each wave of the panel, this is not the case for the works council dummy variable. Specifically, the works council question was asked of all establishments in 1993, 1996, 1998 and 2000, and in the 'missing' years only of panel accessions. For establishments that were not panel accessions in 1997, we proceeded as follows. Interpolation was used if the reported works 
council status was identical either side of this missing year, and the establishment was duly classified as having or not having a works council. However, establishments that reported different works council regimes in 1996 and 1998 were excluded from the sample in the missing year. ${ }^{7}$

For its part, labor input is simply measured by the total number of employees. Note that we did not correct this total by computing full-time equivalents for part-time workers or by adjusting for the lower input per head of apprentices, because of missing values for the hours and productivity of the two groups. But we did seek to take account of these compositional effects by entering the percentage employment shares of part-time workers and apprentices as separate control variables. Furthermore, we also included the percentage share of skilled workers in an attempt to control for differences in the quality of labor inputs. Evidently, hours worked would be a better measure of labor input. Unfortunately, such information as is available on hours worked per week, overtime, and short-time work in the IAB panel does not allow the construction of an "hours worked per year" variable.

The IAB panel does not give any direct information on the capital stock used in the establishment. This is of course a common problem when working with firm-level survey data. As a measure for capital input in year $t$, we use the average amount of replacement investment reported for years $t-1$ and $t$. The basic idea behind this procedure is that the known amount of replacement investment is expected to be proportional to the unknown amount of capital stock. Note, however, that about 30 per cent of all establishments in the sample report a value of zero for replacement investments at least once. This problem has not been dealt with in earlier papers using replacement investment in $t$ as a proxy for capital stock in that year (cf. Frick 2002b). In our study, all firms reporting zero replacement investment in both year $t-1$ and year $t$ are excluded from the sample for year $t$. This reduces our sample by 2,665 observations, or about 17 per cent.

Differences in the quality of the capital stock employed are proxied by two variables: first, a dummy variable indicating whether or not the establishment invested in information and communication technologies in year $t$; and, second, an index indicating the state of technology in year $t$ (ranging from $1=$ "up-to-date" down to $5=$ "very old"). Finally, whether or not an establishment is (contemporaneously) covered by a collective agreement is included as a further control variable, along with dummies for industry, year and eastern Germany.

The empirical models are estimated by OLS based on an unbalanced panel made of pooled data for the four years 1997 to $2000{ }^{8}$ By applying OLS to the unbalanced panel data we do not deal with two issues that now require some discussion, namely, works council 
endogeneity and unobserved firm heterogeneity. As far as the endogeneity issue is concerned, we know that works council presence is not random but is related to establishment size and the structure of the work force, among other things (see Addison, Bellmann, Schnabel, and Wagner, 2002). However, the introduction or presence of a works council is not the result of a rational choice made by the owners or managers of an establishment based on comparing costs and benefits; rather, it is the results of actions taken by the employees. Employee action might well be related the to the past performance of the establishment, but whether an establishment has a works council at a point in time should not be viewed as caused by contemporaneous productivity. We would argue that works council presence is exogenous to an establishment in a sense that allows us to neglect the endogeneity issue in a study of productivity, not least given the enormous difficulties of identifying the works council equation in a convincing manner.

In estimating our translog production function, we did not exploit the panel nature of the data. Although doing so might be expected to solve problems stemming from unobserved differences between establishments, we confronted the practical difficulty that the proportion of establishments in which works councils were introduced or abandoned during the sample period is rather small. For our non-stratified regression sample, which comprises 5,684 establishments, only 117 establishments (or 2 per cent) changed their works council status in either direction. Hence, results based on a fixed-effects panel estimator to control for unobserved time invariant establishment specific influences would be driven by this small sub-sample of establishments. Furthermore, we think that we have good reasons not to be overly concerned with this issue. Unobserved establishment heterogeneity - due, say, to differences in management quality - leads to inconsistent estimates of the works council effect on productivity only if these unobserved characteristics are correlated both with productivity (as we would expect to be the case) and also with the existence of a works council. The latter relation might hold, with workers forming or maintaining a works council when managers are bad and/or a plant shutdown is expected (or alternatively when managers are excellent and they want to increase their piece of the pie), but is this correlation likely to be strong enough to lead to inconsistent estimates in pooled cross sections? If the presence or not of a works council can be considered exogeneous to an establishment (as was argued earlier), then we have good reasons to expect that neglecting the unobserved heterogeneity issue (because the small number of switchers makes the application of fixed effects estimators inappropriate) will not cause inconsistency in the point estimates of works council impact obtained by OLS. 
Our second estimation strategy uses a stochastic production frontier model to estimate technical efficiency in plants with and without a works council. The definitions of output, inputs, and the control variables exactly follow those of the first strategy (pooled OLS estimates) other than in the treatment of the works council. Using pooled data, we first estimate production functions using a fixed effects approach (ignoring the works council status of the plant) to obtain an estimate of the technical efficiency of an establishment. This is constructed from the plant average of the error term over time, corrected for the average industry effect. ${ }^{9}$ The sample is then divided into plants with and without a works council, and we compare the technical efficiency (along with its confidence interval) of the median plant in each regime.

Our third and final approach differs from these two approaches in focusing on productivity growth. The output variable is the difference in an establishment's log total sales between 1997 and 2000. Works council status is indicated by three dummy variables: establishments with a works a council in 1997 and 2000; those without a council in 1997 but with one in 2000; and those with a council in 1997 but without one in 2000. The reference group is thus made up of establishments without a works council in both years. Change in labor input is measured by the difference in the log number of employees in an establishment between 1997 and 2000. We also include changes in the percentage shares of part-time workers, apprentices, and skilled workers to control for compositional changes in the work force. Given the lack of information on the capital stock in the establishment in 1997 and 2000, the change in this input was obtained as follows. We first estimated the capital stock in 1997 by multiplying the two-year average of replacement investment in 1996 and 1997 by six, the assumption being that capital depreciates over six years at a constant rate. For each of the following years, the capital stock is measured as the sum of the capital stock in the previous year plus the amount of extension (i.e. net) investment reported for the current year. In other words, the capital stock in 2000 is given by the two-year average of replacement investment in 1996 and 1997, multiplied by six, plus the sum of extension investments over each of the next three years. ${ }^{10}$ On this occasion, our empirical model uses a Cobb-Douglas type production function, since F-tests did not reject this functional form in favor of the more general translog specification at the 5 percent level. To control for changes in the quality of the capital stock, we included the average value of the dummy variable indicating investment in information and communication technology over the sample period, and the average of the index indicating the state of technology in each year. Finally, coverage by a collective agreement or otherwise is handled via three dummy variables constructed in the same manner 
as the works council dummies. The empirical model(s) was estimated by OLS using a heteroscedasticity-consistent covariance matrix estimator.

\section{Findings}

We next provide results from each of our three estimation strategies, and put them into perspective. ${ }^{11}$ The first procedure it will be recalled uses unbalanced panel data for 1997 to 2000 to estimate translog production functions by OLS. Separate regressions were undertaken for all establishments, for establishments with 21 to 100 employees, and separately for establishments by broad sectors (manufacturing and services) for Germany as a whole and for western and eastern Germany. Our findings are collected in Tables 2, 3, and 4.

[Tables 2 through 4 near here]

Our discussion will focus largely on the estimated coefficient for the works council dummy variable in the various specifications. For the complete sample of all establishments $(11,464$ observations for a total of 5,684 units), a highly significant coefficient of 0.232 is reported in column 1 of Table 2. This implies a beneficial effect of works council presence on productivity of 26.1 per cent. ${ }^{12}$ This effect is somewhat lower (higher) if we look at establishments from western (eastern) Germany only (see column 1, Tables 3 and 4); and it is lower (higher) in establishments from manufacturing (services) in each of the three regions (see columns 3 and 5, Tables 2, 3, and 4). All of these positive coefficient estimates are statistically different from zero at a significance level of 1 per cent or better, and range from 12 per cent (manufacturing establishments in western Germany) to 34.2 percent (services in eastern Germany).

As was discussed in section IV, the flexibility of the translog specification derives from the inclusion of squared employment and capital terms and the interaction of employment and capital. These allow the output elasticities to vary with employment and capital. For the full sample of all establishments with five or more employees (reported in columns 1, 3 and 5 of Tables 2, 3, and 4), these three coefficients are in all cases jointly statistically significant at the 10 per cent level or better. Hence, the more restrictive CobbDouglas formulation is always rejected. For the sub-samples comprising establishments with 21 to 100 employees (reported in columns 2, 4, and 6 of Tables 2, 3, and 4) the Cobb-Douglas specification is not rejected in five out of nine cases. This result is not surprising, however, because there is less reason to believe that the output elasticities will vary within a narrowly defined size class. 
It should be noted that, in the full sample regressions, the squared employment term and the interaction term between employment and capital are in all cases jointly significant (even if neither of them is statistically significant at conventional levels when tested separately). Moreover, in six out of nine cases, each has a negative sign, unambiguously implying that the output elasticity is decreasing in employment. ${ }^{13}$

The output elasticities with respect to employment and capital, which can not directly be observed from the coefficient estimates, are derived according to equation (3) and (4). Since they obviously vary with the quantity of labor and capital used as inputs, we report elasticities at sample means (of the logarithm of each variable) in the lower parts of Tables 2 , 3 , and 4 . The employment elasticity of output varies by sector, size class, and region between 75 and 95 per cent. The capital elasticity is much lower, ranging between 8.2 and 13.4 per cent. In both western and eastern Germany, we observe a higher employment elasticity in manufacturing than in services. Both elasticities are larger in the full sample than in the subsample of establishments with 21 to 100 employees in all but one case (namely, the employment elasticity in the east German service sector). There are no systematic differences between the two regions.

We should add in passing that the estimated coefficients for the control variables indexing the quality of the capital stock (investment in information and computer technology and state of technology) and the labor force (percentage share of part-time workers, apprentices, and skilled workers), as well as dummy variable for establishments from eastern Germany, all have the expected signs and are statistically significant at a conventional level in most cases. On the other hand, the variable indicating coverage by collective bargaining turns out to be insignificant or at best only marginally significant.

Returning to the question that motivates this inquiry, we do not find the magnitude of the estimates of works council impact on productivity reported for establishments with five or more employees to be credible. ${ }^{14}$ Even if there are good theoretical reasons in the collective voice tradition (discussed in section II) to suggest that works councils might have a positive net impact on firm performance, one would not expect effects of this size given that establishments with and without works councils compete in the same market. If correct, the estimates imply that firms would actively encourage the election of a works council. Suffice it to say that there is no indication of this in the broader works council literature.

There are a number of reasons to suspect that estimates from this first step in our empirical investigation of works council effects on productivity are artefacts of the data. One reason could be that size effects are insufficiently controlled for. As pointed out in section V, 
works councils tend to be rare in small establishments and ubiquitous in large ones. If productivity tends to increase with establishment size due to economies of scale, a positive relationship between works council presence and productivity will show up in the data even if there is no causal link between works councils and productivity. We further argued that a partial solution would be to look at establishments from a size interval in which both regimes are reasonably represented and where the rights of the works council are a datum. We now implement this notion by looking at the sub-sample(s) of establishments with 21 to 100 employees. The results are reported in columns 2, 4, and 6 of Tables 2, 3, and 4. Compared with the results earlier reported for the all-establishment sample (with five or more employees), the point estimates for the works council effect are much lower - and even negative for manufacturing establishments in western Germany - and they are insignificant or only marginally significant for four out of nine empirical models. If we look at the two regions and the two broad sectors, the estimated coefficients of the works council dummy variable are positive and significant at the five percent level or better only among establishments in the services sector. For services, productivity appears to be 20.4 (16.6) per cent higher in establishments with a works council in western (eastern) Germany. ${ }^{15}$

But these values are still surprisingly high. If the estimates of the coefficients of the works council dummy in the models using pooled data do after all indicate "true" positive productivity differentials in favor of works councils, we would also expect these effects to show up in identically specified econometric models estimated for repeated cross sections of the data (i.e. for individual years). Furthermore, we would expect the point estimates to be of a similar order of magnitude in 1997, 1998, 1999, and 2000, even if the respective samples will not be identical due to panel attritions and accessions.

[Table 5 near here]

Table 5 gives the coefficient estimates for the works council variable from such repeated cross sections. The general impression from the table is that the point estimates for firms with 21 to 100 employees are not only very often statistically insignificant at conventional levels but also rather volatile from year to year. Looking at service-sector establishments, for example, we observe that the estimated works council effects are statistically insignificant in three out of four years in western and eastern Germany, while the point estimates vary from -7.2 per cent to 36.5 per cent in western Germany and lie between 7.5 and 27.4 per cent for eastern Germany. We interpret this extreme degree of instability over time, coupled with the lack of statistical significance in three out of four years, as 
cautioning against positive effects of works councils on productivity from a translog production function approach.

Our second empirical approach to uncovering the impact of works councils on establishment productivity is to use a stochastic production frontier model. As discussed earlier, the aim is to compare estimates of technical efficiency in plants with and without a works council. Table 6 reports the estimated technical efficiencies and their confidence intervals for the median plant in the two regimes. We feel safer in reporting the median than the mean, because the former should be less prone to outliers. A comparison of the reported values for each of the two groups of establishments within each cell reveals whether one group is more efficient (i.e. produces more output with the same quantity of inputs).

[Table 6 near here]

The median value of the technical efficiency estimates for establishments with a works council exceeds the respective value for establishments without one in all samples. When we focus on establishments with 21 to 100 employees (for the reasons discussed above), however, we see that the 95 percent confidence intervals for the two groups of establishments overlap in all nine cases. In other words, the differences in the values are not statistically significant at conventional levels. Therefore, there is no clear-cut evidence from the stochastic production frontier model that works councils are either good or bad for technical efficiency.

[Table 7 near here]

Our final approach differs from the other tests in considering works council impact on the growth in productivity between 1997 and 2000. ${ }^{16}$ Results of this alternative, firstdifference approach are reported in Table 7. In the model, establishments without a works council in both the starting year (1997) and in the end year (2000) form the reference group. Compared with these firms, the estimates in he first row of the table indicate that establishments with a works council in both years did not record a different performance on average - none of the coefficient estimates is statistically different from zero at conventional levels. The same holds for establishments in which a works council was set up during the sample period under investigation, and indeed for most samples of establishments in which the works council ceased to exist after 1997. ${ }^{17}$

The output elasticity with respect to employment is on average 64 per cent and has fallen by exactly one third vis-a-vis the regressions using levels of variables (see Tables 2 through 5). It is larger in manufacturing than in services and, somewhat surprisingly, it is larger for eastern than for western Germany. By contrast, controlling for other factors, the average growth in output is found to be larger for western Germany. But the coefficient 
estimate for the change in the capital stock is positive and statistically significant in just two out of six models. Similarly, the coefficients of the control variables are insignificant in almost all cases. The general insignificance of these covariates may reflect insufficient variation in the control variables, as well as measurement error which becomes more important when differencing. As a result, the change in employment accounts for almost all of the explained variation in output change. The bottom line of this exercise is that the works council has neither a positive nor a negative effect on productivity growth.

In summary, we have analyzed works councils' productivity effects from three different perspectives. The evidence points in the same direction: they seemingly neither reduce nor enhance productivity, technical efficiency, or productivity growth. Accordingly, their massive effect on productivity as reported in earlier studies based on the IAB Establishment Panel do not survive disaggregation by broad sector and region.

\section{Conclusions}

We are now into the third stage of research into the effect of German works councils on firm performance that uses data from the nationally representative IAB Establishment Panel. The evidence supplied here suggests that harsh dismissal of the institution based on rent seeking considerations or slowed decision taking is just as misplaced as the view that the presence of a works council is a productivity cure-all while also delivering on industrial democracy. Arguably, the former position was commonplace by the end of the first stage of economic research on work councils, while the second has recently been gaining currency as a result of some very optimistic estimates of works council impact using the IAB data.

In addressing works council effects on productivity, 1997-2000, the present study has performed three separate tests: the first strategy was to recoup the works council effect directly by estimating translog production functions that include a works council dummy, using pooled data and OLS methods; the second approach estimated a stochastic production frontier model using fixed effects to compare the technical efficiency of the median works council plant with that of its works-council-free counterpart; and the third test offered a modified first-difference model linking productivity growth to (changes in) works council status. Consistent with other research, for the sample of all establishments, the results of the first exercise pointed to positive and well-defined works council effects on productivity of around 25 per cent. The problem is that in estimating production functions across this sample, we are not accounting for differences in works council power or in works council coverage, both of which are influenced by establishment size. Since productivity will also be related to 
establishment size where there are economies of scale, there is the possibility that the observed productivity differential in favor of works councils may be a chimera. As a partial solution to this problem, given the lack of plausible identifying instruments for works council presence and no independent information on works council type, we presented results for a subsample of plants with between 21 and 100 workers. Over this employment range, the legal powers of the council are a datum and works councils plants are found in roughly one-third of the sample. The coefficient estimates for the works council dummy (a) plummeted, (b) were actually negative albeit statistically insignificant for the crucial west German manufacturing sector, and (c) were statistically insignificant in three out of the four unstacked cross sections.

For their part, our frontier production function tests revealed a similar pattern of results. For the all-plant sample it was found that the technical efficiency of the median works council plant everywhere exceeded that of its counterpart works-council-free plant. For the restricted sample of plants with 21-100 employees, however, the differences were nowhere statistically significant. And although the results of our final test are inherently more speculative because of measurement error and the small number of switchers, they too support the notion that there are likely to be few differences on average between plants with works councils and plants without them.

The finding that there are no works council effects on average is not unimportant in its own right given the history of German research in this area. Thus, for example, it suggests that the pessimistic findings of the early (i.e. first phase) literature are unrepresentative, unless there has been a sea change in the indus trial relation climate in recent years - or perhaps in the market environment. But for the future it will be necessary to go behind these average effects. In this connection, we might usefully note that in reestimating their earlier (phase one) production function study which had pointed to sharply lower total factor productivity in works council firms, FitzRoy and Kraft were to report that such effects could be undone by profit sharing (see, FitzRoy and Kraft, 1987, 1995). It would be interesting to see if similar improvements - from a non-negative average effect - are discernible in future waves of the panel providing more data points on profit sharing. Finally, to the list of things we need to know more about, there are performance outcomes other than productivity. One such outcome that has been examined using IAB data is plant closings. Another that has yet to be examined is profitability. That being said, each measure is inherently more ambiguous from an efficiency perspective than the indicator examinedhere. 


\section{References}

Addison, John T., Lutz Bellmann, and Arnd Kölling (2004), 'Works Councils and Plant Closings in Germany,' Unpublished paper, Department of Economics, University of South Carolina. [Forthcoming: British Journal of Industrial Relations, March 2004.]

Addison, John T., Lutz Bellmann, Claus Schnabel, and Joachim Wagner (2002), 'German Works Councils Old and New: Incidence, Coverage and Determinants,' Discussion Paper No. 495, Bonn: Institute for the Study of Labor (IZA).

Addison, John T., Lutz Bellmann, Claus Schnabel, and Joachim Wagner. (2003), 'The Reform of the German Works Constitution Act: A Critical Appraisal'. Industrial Relations [in press].

Addison, John T., Kornelius Kraft, and Joachim Wagner (1993), 'German Works Council and Firm Performance,' in Bruce E. Kaufman and Morris M. Kleiner (eds.), Employee Representation: Alternatives and Future Directions, Madison, WI: Industrial Relations Research Association, pp. 305-338.

Addison, John T., Claus Schnabel, and Joachim Wagner (1996), 'German Works Councils, Profits and Innovation,' Kyklos 49 (4): 555-582.

Addison, John T., Claus Schnabel, and Joachim Wagner (2001), 'Works Councils in Germany: Their Effects on Establishment Performance,' Oxford Economic Papers 53 (October): 659-94.

Addison, John T., Claus Schnabel, and Joachim Wagner (2003), 'The Course of Research into the Economic Consequences of German Work Councils,' Unpublished paper, Department of Economics, University of South Carolina. [Forthcoming: British Journal of Industrial Relations, 2004.]

Addison, John T., and Joachim Wagner (1997), 'The Impact of German Works Councils on Profitability and Innovation: New Evidence from Micro Data,' Jahrbücher für Nationalökonomie und Statistik 216 (1): 1-20.

Aigner, Dennis, C.A. Knox Lovell, and Peter Schmidt (1977), 'Formulation and Estimation of Stochastic Frontier Production Function Models,' Journal of Econometrics 6 (July): 21-37.

Brown, Charles, and James Medoff (1978), 'Trade Unions in the Production Process,' Journal of Political Economy 86 (June): 355-378.

Christensen, Laurits R., Dale W. Jorgensen, and Lawrence J. Lau (1971), 'Conjugate Duality and the Transcendental Logarithmic Production Function,' Econometrica 39 (July): 255-256.

Christensen, Laurits R., Dale W. Jorgensen, and Lawrence J. Lau (1973), 'Transcendental Logarithmic Production Frontier,' The Review of Economics and Statistics 55 (February): 2845 .

Denny, Michael, and Melvyn Fuss (1977), 'The Use of Approximation Analysis to Test for Separability and the Existence of Consistent Aggregates,' The American Economic Review 67 (3): 404-418.

Dilger, Alexander (2002), Ökonomik betrieblicher Mitbestimmung, Munich and Mering: Rainer Hampp Verlag. 
FitzRoy, Felix, and Kornelius Kraft (1985), 'Unionization, Wages, and Efficiency: Theories and Evidence from the U.S. and West Germany,' Kyklos 38 (4): 537-54.

FitzRoy, Felix, and Kornelius Kraft (1987), 'Efficiency and Internal Organization: Works Councils in West German Firms,' Economica 54 (November): 493-504.

FitzRoy, Felix, and Kornelius Kraft (1990), 'Innovation, Rent-Sharing and the Organization of Labor in the Federal Republic of Germany,' Small Business Economics 2 (2): 95-103.

FitzRoy, Felix, and Kornelius Kraft (1995). 'On The Choice of Incentives in Firms,' Journal of Economic Behavior and Organization 26 (January): 145-160.

Freeman, Richard B. (1976), 'Individual Mobility and Union Voice in the Labor Market,' American Economic Review, Papers and Proceedings 66 (May): 361-368.

Freeman, Richard B., and Edward P. Lazear (1995), 'An Economic Analysis of Works Councils'. In Joel Rogers and Wolfgang Streeck (eds.), Works Councils: Consultation, Representation, and Cooperation in Industrial Relations, Chicago, Ill.: University of Chicago Press, pp. 27-50.

Freeman, Richard B., and James L. Medoff, (1984), What Do Unions Do? New York: Basic Books.

Frick, Bernd (2001). 'High Performance Practices und betriebliche Mitbestimmung: Komplementär oder substitutiv? - Empirische Befunde für den deutschen Maschinenbau,' Wittener Diskussionspapiere, Heft Nr. 88, Universität Witten-Herdecke.

Frick, Bernd (2002a), 'Mandated Codetermination, Voluntary Profit Sharing and Firm Performance,' Unpublished paper, University of Witten-Herdecke.

Frick, Bernd (2002b), 'Ökonomische Analyse der Deutschen Betriebsverfassung,' in: Dieter Sadowski and Ulrich Walwei (eds.), Die Ökonomische Analyse des Arbeitsrechts: IABKontaktseminar vom 12.-16. November 2001 im Institut für Arbeitsrecht und Arbeitsbeziehungen in der Europäischen Gemeinschaft (IAAG) der Universität Trier, Beiträge zur Arbeitsmarkt- und Berufsforschung 259, IAB, Nürnberg, pp. 213-236.

Hübler, Olaf, and Uwe Jirjahn, U. (2001). 'Works Councils and Collective Bargaining in Germany: The Impact on Productivity and Wage s,' Discussion Paper No. 332, Bonn: Institute for the Study of Labor (IZA).

Jirjahn, Uwe (2002), 'Executive Incentives, Works Councils and Firm Performance,' Unpublished paper, University of Hannover.'

Kölling, Arnd (2000), 'The IAB Establishment Panel,' Journal of Applied Social Science Studies 120 (2): 291-300.

Kommission Mitbestimmung (1998). Mitbestimmung und neue Unternehmenskulturen Bilanz und Perspektiven. Gütersloh: Verlag Bertelsmann Stiftung.

Kotthoff, Hermann (1994), Betriebsräte und Bürgerstatus: Wandel und Kontinuität betrieblicher Interessenvertretung, Munich and Mering: Rainer Hampp Verlag.

Kraft, Kornelius (1986), 'Exit and Voice in the Labour Market: An Empirical Study of Quits,' Journal of Institutional and Theoretical Economics 142 (December): 697-715. 
Kuhn, Peter (1985), 'Union Productivity

Effects and Economic Efficiency,' Journal of Labor Research 6 (Summer): 229-248.

Levine, David I., and Laura D'Andrea Tyson (1990), 'Participation, Productivity, and the Firm's Environment,' in Alan S. Blinder (ed.), Paying for Productivity - A Look at the Evidence, Washington, D.C.: The Brookings Institution, pp. 182-237.

Meeusen, Wim, and Julien van den Broeck (1977), 'Efficiency Estimation from CobbDouglas Production Functions with Composed Error,' International Economic Review 18 (June): 435-444.

Müller-Jentsch, Walther (1995), 'Germany: From Collective Voice to Co-Management,' in Joel Rogers and Wolfgang Streeck (eds.), Works Councils: Consultation, Representation, and Cooperation in Industrial Relations, Chicago, Ill.: University of Chicago Press, pp. 53-78.

Official Journal (2002), 'Directive 2002/14/EC of the European Parliament and the Council of 11 March 2002 Establishing a General Framework for Informing and Consulting Employees in the European Community, Official Journal of the European Communities L 80 of 23.3.2003: 29-33.

Schank, Thorsten, Claus Schnabel, and Joachim Wagner (2002), 'Works Councils - Sand or Grease in the Operation of German Firms?' Working Paper 281, Faculty of Economics and Social Sciences, University of Lüneburg.

Schmalwasser, Oda (2001), 'Revision der Anlagevermögensrechnung 1991 bis 2001,' Wirtschaft und Statistik 5: 342-356.

Schnabel, Claus, and Joachim Wagner (1994), 'Industrial Relations and Trade Union Effects on Innovation in Germany', Labour 8: 489-503.

Schmidt, Peter, and Robin C. Sickles (1984), 'Production Frontiers and Panel Data,' Journal of Business and Economic Statistics 2 (October): 367-374.

Williamson, Oliver E., Michael L. Wachter, and Jeffrey E. Harris (1975), 'Understanding the Employment Relation: The Analysis of Idiosyncratic Exchange,' Bell Journal of Economics 6 (Spring): 250-278.

Wolf, Elke, and Thomas Zwick (2002), 'Reassessing the Impacts of High Performance Workplaces,' ZEW Discussion Paper No. 02-07, Mannheim: Zentrum für Europäische Wirtschaftsforschung/ Center for European Economic Research. 
Table 1: Works Councils Presence in Establishments (Percentages)

\begin{tabular}{|c|c|c|c|c|c|c|}
\hline & \multicolumn{2}{|c|}{ Total } & \multicolumn{2}{|c|}{ Manufacturing } & \multicolumn{2}{|c|}{ Services } \\
\hline & $\mathrm{N} \geq 5$ & $100 \geq N \geq 21$ & $\mathrm{~N} \geq 5$ & $100 \geq N \geq 21$ & $N \geq 5$ & $100 \geq N \geq 21$ \\
\hline & \multicolumn{6}{|c|}{ Weighted } \\
\hline Germany & 11.7 & 28.5 & 14.0 & 31.6 & 11.0 & 26.3 \\
\hline $\begin{array}{l}\text { western } \\
\text { Germany }\end{array}$ & 12.0 & 29.0 & 15.3 & 34.3 & 10.8 & 25.8 \\
\hline $\begin{array}{l}\text { eastern } \\
\text { Germany }\end{array}$ & 10.6 & 26.0 & 9.3 & 22.7 & 12.0 & 28.9 \\
\hline & \multicolumn{6}{|c|}{ Unweighted } \\
\hline Germany & 42.7 & 33.5 & 49.3 & 34.8 & 34.3 & 30.2 \\
\hline $\begin{array}{l}\text { western } \\
\text { Germany }\end{array}$ & 49.7 & 36.6 & 64.1 & 44.6 & 34.7 & 28.2 \\
\hline $\begin{array}{l}\text { eastern } \\
\text { Germany }\end{array}$ & 34.1 & 30.3 & 34.6 & 27.9 & 33.9 & 32.9 \\
\hline
\end{tabular}

Source: IAB-Establishment Panel, 1997-2000. 
Table 2: OLS Regressions of a Translog Production Function (pooled estimates, 1997 -2000; dependent variable: total sales $(\log Y))$

\begin{tabular}{|c|c|c|c|c|c|c|}
\hline \multirow[b]{2}{*}{$\begin{array}{l}\text { Establishment } \\
\text { Size }\end{array}$} & \multicolumn{2}{|c|}{ Total } & \multicolumn{2}{|c|}{ Manufacturing } & \multicolumn{2}{|c|}{ Services } \\
\hline & $N \geq 5$ & $100 \geq N \geq 21$ & $N \geq 5$ & $100 \geq N \geq 21$ & $N \geq 5$ & $100 \geq N \geq 21$ \\
\hline & (1) & (2) & (3) & (4) & (5) & (6) \\
\hline $\begin{array}{l}\text { Works council } \\
\text { (dummy: } 1 \text { = yes) }\end{array}$ & $\begin{array}{l}0.232 \\
{[8.88]^{\star * *}}\end{array}$ & $\begin{array}{l}0.118 \\
{[3.22]^{\star \star *}}\end{array}$ & $\begin{array}{l}0.177 \\
{[5.71]^{\star * *}}\end{array}$ & $\begin{array}{l}0.046 \\
{[1.03]}\end{array}$ & $\begin{array}{l}0.275 \\
{[6.31]^{\star * *}}\end{array}$ & $\begin{array}{l}0.183 \\
{[3.05]^{\star * *}}\end{array}$ \\
\hline $\begin{array}{l}\text { Number of } \\
\text { employees } \\
(\log N)\end{array}$ & $\begin{array}{l}1.041 \\
{[17.80]^{\star * *}}\end{array}$ & $\begin{array}{l}0.446 \\
{[0.70]}\end{array}$ & $\begin{array}{l}1.117 \\
{[15.92]^{\star * *}}\end{array}$ & $\begin{array}{l}0.228 \\
{[0.30]}\end{array}$ & $\begin{array}{l}1.075 \\
{[11.92]^{\star * *}}\end{array}$ & $\begin{array}{l}0.629 \\
{[0.60]}\end{array}$ \\
\hline $\begin{array}{l}\text { Capital stock } \\
(\log K)\end{array}$ & $\begin{array}{l}-0.075 \\
{[1.59]}\end{array}$ & $\begin{array}{l}-0.168 \\
{[1.70]^{*}}\end{array}$ & $\begin{array}{l}-0.098 \\
{[1.89]^{*}}\end{array}$ & $\begin{array}{l}-0.063 \\
{[0.41]}\end{array}$ & $\begin{array}{l}-0.072 \\
{[0.96]}\end{array}$ & $\begin{array}{l}-0.257 \\
{[2.01]^{\star \star}}\end{array}$ \\
\hline $\log ^{2} N$ & $\begin{array}{l}-0.025 \\
{[1.59]}\end{array}$ & $\begin{array}{l}0.132 \\
{[0.79]}\end{array}$ & $\begin{array}{l}-0.023 \\
{[1.20]}\end{array}$ & $\begin{array}{l}0.171 \\
{[0.77]}\end{array}$ & $\begin{array}{l}-0.029 \\
{[1.32]}\end{array}$ & $\begin{array}{l}0.092 \\
{[0.35]}\end{array}$ \\
\hline $\log ^{2} K$ & 0.017 & 0.026 & 0.019 & 0.013 & 0.02 & 0.037 \\
\hline $\log N \log K$ & $\begin{array}{l}-0.004 \\
{[0.43]}\end{array}$ & $\begin{array}{l}-0.009 \\
{[0.44]}\end{array}$ & $\begin{array}{l}{[<.7]} \\
-0.006 \\
{[0.54]}\end{array}$ & $\begin{array}{l}{[1.001} \\
0.001 \\
{[0.04]}\end{array}$ & {$[1.03]$} & $\begin{array}{l}-0.018 \\
{[0.63]}\end{array}$ \\
\hline $\begin{array}{l}\text { Investment in ICT } \\
\text { (dummy: } 1 \text { = yes) }\end{array}$ & $\begin{array}{l}0.124 \\
{[7.55]^{\star * *}}\end{array}$ & $\begin{array}{l}0.096 \\
{[3.72]^{\star * *}}\end{array}$ & $\begin{array}{l}0.105 \\
{[5.75]^{\star * *}}\end{array}$ & $\begin{array}{l}0.051 \\
{[1.72]^{*}}\end{array}$ & $\begin{array}{l}0.145 \\
{[4.88]^{\star * *}}\end{array}$ & $\begin{array}{l}0.147 \\
{[3.38]^{* * *}}\end{array}$ \\
\hline $\begin{array}{l}\text { State of technology } \\
\text { (index: } 1=\text { up - to- } \\
\text { date; } 5=\text { very old) }\end{array}$ & $\begin{array}{l}-0.082 \\
{[7.71]^{\star \star \star}}\end{array}$ & $\begin{array}{l}-0.083 \\
{[4.62]^{\star \star *}}\end{array}$ & $\begin{array}{l}-0.076 \\
{[6.36]^{\star * *}}\end{array}$ & $\begin{array}{l}-0.077 \\
{[3.74]^{\star \star \star}}\end{array}$ & $\begin{array}{l}-0.085 \\
{[4.57]^{\star \star *}}\end{array}$ & $\begin{array}{l}-0.101 \\
{[3.29]^{\star \star *}}\end{array}$ \\
\hline $\begin{array}{l}\text { Part-time workers } \\
\text { (percentage) }\end{array}$ & $\begin{array}{l}-0.992 \\
{[15.26]^{\star * *}}\end{array}$ & $\begin{array}{l}-1.02 \\
{[9.24]^{* * *}}\end{array}$ & $\begin{array}{l}-1.455 \\
{[15.36]^{* * *}}\end{array}$ & $\begin{array}{l}-1.544 \\
{[9.28]^{\star \star *}}\end{array}$ & $\begin{array}{l}-0.735 \\
{[9.09]^{* * *}}\end{array}$ & $\begin{array}{l}-0.817 \\
{[6.28]^{* * *}}\end{array}$ \\
\hline $\begin{array}{l}\text { Apprentices } \\
\text { (percentage) }\end{array}$ & $\begin{array}{l}-0.892 \\
{[7.46]^{* * *}}\end{array}$ & $\begin{array}{l}-0.761 \\
{[3.23]^{\star * *}}\end{array}$ & $\begin{array}{l}-1.114 \\
{[8.72]^{\star * *}}\end{array}$ & $\begin{array}{l}-1.506 \\
{[6.24]^{* * *}}\end{array}$ & $\begin{array}{l}-0.567 \\
{[2.62]^{* * *}}\end{array}$ & $\begin{array}{l}0.162 \\
{[0.37]}\end{array}$ \\
\hline $\begin{array}{l}\text { Skilled workers } \\
\text { (percentage) }\end{array}$ & $\begin{array}{l}0.344 \\
{[9.61]^{\star * *}}\end{array}$ & $\begin{array}{l}0.379 \\
{[6.16]^{\star * *}}\end{array}$ & $\begin{array}{l}0.234 \\
{[5.43]^{\star * *}}\end{array}$ & $\begin{array}{l}0.305 \\
{[3.60]^{* * *}}\end{array}$ & $\begin{array}{l}0.432 \\
{[7.73]^{* \star *}}\end{array}$ & $\begin{array}{l}0.391 \\
{[4.49]^{* * *}}\end{array}$ \\
\hline $\begin{array}{l}\text { Collective } \\
\text { agreement } \\
\text { (dummy: } 1=\text { yes) }\end{array}$ & $\begin{array}{l}0.037 \\
{[1.88]^{*}}\end{array}$ & $\begin{array}{l}0.034 \\
{[1.10]}\end{array}$ & $\begin{array}{l}0.019 \\
{[0.92]}\end{array}$ & $\begin{array}{l}0.034 \\
{[0.91]}\end{array}$ & $\begin{array}{l}0.086 \\
{[2.27]^{\star *}}\end{array}$ & $\begin{array}{l}0.06 \\
{[1.10]}\end{array}$ \\
\hline $\begin{array}{l}\text { eastern Germany } \\
\text { (dummy) }\end{array}$ & $\begin{array}{l}-0.355 \\
{[16.63]^{\star \star *}}\end{array}$ & $\begin{array}{l}-0.33 \\
{[9.27]^{\star \star *}}\end{array}$ & $\begin{array}{l}-0.298 \\
{[12.55]^{\star \star *}}\end{array}$ & $\begin{array}{l}-0.267 \\
{[5.99]^{\star * *}}\end{array}$ & $\begin{array}{l}-0.417 \\
{[11.37]^{* * *}}\end{array}$ & $\begin{array}{l}-0.42 \\
{[7.24]^{\star \star \star}}\end{array}$ \\
\hline Constant & $\begin{array}{l}11.976 \\
{[5105]^{\star * *}}\end{array}$ & 13.914 & $\begin{array}{l}11.986 \\
{[48.35]^{* * *}}\end{array}$ & $\begin{array}{l}13.803 \\
{[8.40]^{* * *}}\end{array}$ & 12.597 & 14.665 \\
\hline $\begin{array}{l}\text { Output elasticities } \\
\text { at sample means }\end{array}$ & & & & & & \\
\hline$\varepsilon_{Y N}$ & 0.892 & 0.835 & 0.945 & 0.894 & 0.833 & 0.763 \\
\hline$p$-value & $\begin{array}{l}{[0.000]} \\
0.122\end{array}$ & $\begin{array}{l}{[0.000]} \\
0.105\end{array}$ & $\begin{array}{l}{[0.000]} \\
0.114\end{array}$ & $\begin{array}{l}{[0.000]} \\
0.093\end{array}$ & $\begin{array}{l}{[0.000]} \\
0.124\end{array}$ & $\begin{array}{l}{[0.000]} \\
0.113\end{array}$ \\
\hline $\begin{array}{l}\varepsilon_{Y K} \\
p \text {-value }\end{array}$ & $\begin{array}{l}0.122 \\
{[0.000]}\end{array}$ & {$[0.000]$} & {$[0.000]$} & {$[0.000]$} & {$[0.000]$} & {$[0.000]$} \\
\hline No. of observations & 11465 & 3595 & 6870 & 1987 & 4595 & 1608 \\
\hline $\begin{array}{l}\text { No. of plants } \\
\mathrm{R}^{2}\end{array}$ & $\begin{array}{l}5684 \\
0.90\end{array}$ & $\begin{array}{l}1839 \\
0.60\end{array}$ & $\begin{array}{l}3413 \\
0.93\end{array}$ & $\begin{array}{l}1032 \\
0.57\end{array}$ & $\begin{array}{l}2271 \\
0.83\end{array}$ & $\begin{array}{l}807 \\
0.62\end{array}$ \\
\hline
\end{tabular}

Notes: Regressions also include sector and year dummies.

${ }^{* * *},{ }^{* *},{ }^{*}$ denote significance at the $.01, .05$, and .10 levels, respectively. 
Table 3: OLS Regressions of a Translog Production Function - western Germany (pooled estimates, 1997-2000; dependent variable: total sales ( $\log Y)$ )

\begin{tabular}{|c|c|c|c|c|c|c|}
\hline & & otal & Man & acturing & & vices \\
\hline $\begin{array}{l}\text { Establishment } \\
\text { Size }\end{array}$ & $N \geq 5$ & $100 \geq N \geq 21$ & $N \geq 5$ & $100 \geq N \geq 21$ & $N \geq 5$ & $100 \geq N \geq 21$ \\
\hline & (1) & (2) & (3) & (4) & (5) & (6) \\
\hline $\begin{array}{l}\text { Works council } \\
\text { (dummy: } 1 \text { = yes) }\end{array}$ & $\begin{array}{l}0.206 \\
{[5.21]^{\star * *}}\end{array}$ & $\begin{array}{l}0.098 \\
{[1.80]^{*}}\end{array}$ & $\begin{array}{l}0.113 \\
{[2.59]^{\star * *}}\end{array}$ & $\begin{array}{l}-0.042 \\
{[0.71]}\end{array}$ & $\begin{array}{l}0.27 \\
{[4.14]^{* * *}}\end{array}$ & $\begin{array}{l}0.186 \\
{[2.04]^{\star *}}\end{array}$ \\
\hline $\begin{array}{l}\text { Number of } \\
\text { employees } \\
(\log N)\end{array}$ & $\begin{array}{l}1.028 \\
{[12.05]^{\star \star \star}}\end{array}$ & $\begin{array}{l}0.952 \\
{[0.95]}\end{array}$ & $\begin{array}{l}1.29 \\
{[14.32]^{\star \star \star}}\end{array}$ & $\begin{array}{l}1.118 \\
{[0.93]}\end{array}$ & $\begin{array}{l}0.993 \\
{[7.71]^{\star \star \star}}\end{array}$ & $\begin{array}{l}1.036 \\
{[0.69]}\end{array}$ \\
\hline $\begin{array}{l}\text { Capital stock } \\
(\log K)\end{array}$ & $\begin{array}{l}-0.058 \\
{[0.81]}\end{array}$ & $\begin{array}{l}-0.327 \\
{[2.13]^{\star \star}}\end{array}$ & $\begin{array}{l}-0.119 \\
{[1.67]^{*}}\end{array}$ & $\begin{array}{l}0.001 \\
{[0.00]}\end{array}$ & $\begin{array}{l}-0.053 \\
{[0.46]}\end{array}$ & $\begin{array}{l}-0.49 \\
{[2.68]^{* * *}}\end{array}$ \\
\hline $\log ^{2} N$ & $\begin{array}{l}-0.026 \\
{[1.17]}\end{array}$ & $\begin{array}{l}-0.09 \\
{[0.36]}\end{array}$ & $\begin{array}{l}0.011 \\
{[0.56]}\end{array}$ & $\begin{array}{l}-0.034 \\
{[0.10]}\end{array}$ & $\begin{array}{l}-0.056 \\
{[1.89]^{\star}}\end{array}$ & $\begin{array}{l}-0.123 \\
{[0.34]}\end{array}$ \\
\hline $\log ^{2} K$ & $\begin{array}{l}0.015 \\
{[167]^{*}}\end{array}$ & 0.032 & 0.03 & 0.012 & 0.011 & 0.046 \\
\hline $\log N \log K$ & $\begin{array}{l}-0.001 \\
{[0.10]}\end{array}$ & $\begin{array}{l}0.015 \\
{[0.40]}\end{array}$ & $\begin{array}{l}-0.03 \\
{[2.50]^{* *}}\end{array}$ & $\begin{array}{l}-0.01 \\
{[0.24]}\end{array}$ & $\begin{array}{l}0.007 \\
{[0.46]}\end{array}$ & $\begin{array}{l}0.014 \\
{[0.24]}\end{array}$ \\
\hline $\begin{array}{l}\text { Investment in ICT } \\
\text { (dummy: } 1 \text { = yes) }\end{array}$ & $\begin{array}{l}0.104 \\
{[4.18]^{\star \star \star}}\end{array}$ & $\begin{array}{l}0.115 \\
{[2.82]^{\star \star \star}}\end{array}$ & $\begin{array}{l}0.088 \\
{[3.18]^{\star \star \star}}\end{array}$ & $\begin{array}{l}0.075 \\
{[1.67]^{\star}}\end{array}$ & $\begin{array}{l}0.112 \\
{[2.63]^{\star \star \star}}\end{array}$ & $\begin{array}{l}0.15 \\
{[2.29]^{\star \star}}\end{array}$ \\
\hline $\begin{array}{l}\text { State of technology } \\
\text { (index: } 1=\text { up-to- } \\
\text { date; } 5=\text { very old) }\end{array}$ & $\begin{array}{l}-0.053 \\
{[3.62]^{\star \star \star}}\end{array}$ & $\begin{array}{l}-0.067 \\
{[2.49]^{* *}}\end{array}$ & $\begin{array}{l}-0.036 \\
{[2.26]^{\star *}}\end{array}$ & $\begin{array}{l}-0.038 \\
{[1.29]}\end{array}$ & $\begin{array}{l}-0.064 \\
{[2.56]^{\star \star}}\end{array}$ & $\begin{array}{l}-0.102 \\
{[2.39]^{\star \star}}\end{array}$ \\
\hline $\begin{array}{l}\text { Part-time workers } \\
\text { (percentage) }\end{array}$ & $\begin{array}{l}-1.049 \\
{[11.91]^{\star * *}}\end{array}$ & $\begin{array}{l}-1.018 \\
{[6.43]^{\star \star *}}\end{array}$ & $\begin{array}{l}-1.317 \\
{[9.89]^{\star * *}}\end{array}$ & $\begin{array}{l}-1.598 \\
{[7.36]^{* * *}}\end{array}$ & $\begin{array}{l}-0.862 \\
{[7.97]^{* * *}}\end{array}$ & $\begin{array}{l}-0.724 \\
{[3.67]^{* * *}}\end{array}$ \\
\hline $\begin{array}{l}\text { Apprentices } \\
\text { (percentage) }\end{array}$ & $\begin{array}{l}-1.175 \\
{[5.56]^{\star \star \star}}\end{array}$ & $\begin{array}{l}-1.042 \\
{[2.30]^{\star *}}\end{array}$ & $\begin{array}{l}-1.555 \\
{[6.18]^{\star \star \star}}\end{array}$ & $\begin{array}{l}-2.51 \\
{[6.19]^{\star \star \star}}\end{array}$ & $\begin{array}{l}-0.786 \\
{[2.45]^{\star \star}}\end{array}$ & $\begin{array}{l}0.189 \\
{[0.27]}\end{array}$ \\
\hline $\begin{array}{l}\text { Skilled workers } \\
\text { (percentage) }\end{array}$ & $\begin{array}{l}0.446 \\
{[8.80]^{\star \star \star}}\end{array}$ & $\begin{array}{l}0.412 \\
{[4.46]^{\star * *}}\end{array}$ & $\begin{array}{l}0.293 \\
{[4.92]^{\star \star *}}\end{array}$ & $\begin{array}{l}0.291 \\
{[2.56]^{\star *}}\end{array}$ & $\begin{array}{l}0.576 \\
{[7.52]^{\star \star *}}\end{array}$ & $\begin{array}{l}0.475 \\
{[3.69]^{\star * *}}\end{array}$ \\
\hline $\begin{array}{l}\text { Collective } \\
\text { agreement } \\
\text { (dummy: } 1=\text { yes) }\end{array}$ & $\begin{array}{l}0.008 \\
{[0.24]}\end{array}$ & $\begin{array}{l}0.012 \\
{[0.21]}\end{array}$ & $\begin{array}{l}-0.021 \\
{[0.62]}\end{array}$ & $\begin{array}{l}-0.035 \\
{[0.55]}\end{array}$ & $\begin{array}{l}0.073 \\
{[1.34]}\end{array}$ & $\begin{array}{l}0.043 \\
{[0.49]}\end{array}$ \\
\hline Constant & $\begin{array}{l}11.837 \\
{[29.28]^{\star * *}}\end{array}$ & $\begin{array}{l}13.256 \\
{[5.85]^{\star \star *}}\end{array}$ & $\begin{array}{l}11.642 \\
{[27.51]^{\star * *}}\end{array}$ & $\begin{array}{l}11.091 \\
{[4.43]^{\star * *}}\end{array}$ & $\begin{array}{l}12.572 \\
{[21.78]^{\star * *}}\end{array}$ & $\begin{array}{l}15.283 \\
{[4.71]^{\star * *}}\end{array}$ \\
\hline $\begin{array}{l}\text { Output elasticities } \\
\text { at sample means }\end{array}$ & & & & & & \\
\hline$\varepsilon_{Y N}$ & 0.900 & 0.789 & 0.943 & 0.860 & 0.872 & 0.748 \\
\hline$p$-value & {$[0.000]$} & {$[0.000]$} & {$[0.000]$} & [0.000] & {$[0.000]$} & {$[0.000]$} \\
\hline$\varepsilon_{Y K}$ & 0.127 & 0.109 & 0.134 & 0.102 & 0.106 & 0.102 \\
\hline$p$-value & {$[0.000]$} & {$[0.000]$} & {$[0.000]$} & [0.000] & {$[0.000]$} & {$[0.000]$} \\
\hline No. of observations & 5843 & 1646 & 3347 & 789 & 2496 & 857 \\
\hline No. of plants & 3120 & 944 & 1717 & 439 & 1403 & 505 \\
\hline$R^{2}$ & 0.91 & 0.55 & 0.94 & 0.61 & 0.84 & 0.54 \\
\hline
\end{tabular}

Notes: Regressions also include sector and year dummies.

${ }^{* * *},{ }^{* *},{ }^{*}$ denote significance at the $.01, .05$, and .10 levels, respectively. 
Table 4: OLS Regressions of a Translog Production Function - eastern Germany (pooled estimates, 1997-2000; dependent variable: total sales ( $\log Y)$ )

\begin{tabular}{|c|c|c|c|c|c|c|}
\hline & & otal & Man & acturing & & vices \\
\hline $\begin{array}{l}\text { Establishment } \\
\text { Size }\end{array}$ & $N \geq 5$ & $100 \geq N \geq 21$ & $N \geq 5$ & $100 \geq N \geq 21$ & $N \geq 5$ & $100 \geq N \geq 21$ \\
\hline & (1) & (2) & (3) & (4) & (5) & (6) \\
\hline $\begin{array}{l}\text { Works council } \\
\text { (dummy: } 1 \text { = yes) }\end{array}$ & $\begin{array}{l}0.266 \\
{[7.77]^{\star * *}}\end{array}$ & $\begin{array}{l}0.137 \\
{[2.84]^{\star * *}}\end{array}$ & $\begin{array}{l}0.222 \\
{[5.25]^{\star * *}}\end{array}$ & $\begin{array}{l}0.111 \\
{[1.85]^{*}}\end{array}$ & $\begin{array}{l}0.294 \\
{[5.17]^{* * *}}\end{array}$ & $\begin{array}{l}0.154 \\
{[1.98]^{\star *}}\end{array}$ \\
\hline $\begin{array}{l}\text { Number of } \\
\text { employees } \\
(\log N)\end{array}$ & $\begin{array}{l}1.149 \\
{[12.57]^{\star \star *}}\end{array}$ & $\begin{array}{l}0.237 \\
{[0.30]}\end{array}$ & $\begin{array}{l}1.085 \\
{[9.89]^{\star \star \star}}\end{array}$ & $\begin{array}{l}-0.143 \\
{[0.16]}\end{array}$ & $\begin{array}{l}1.19 \\
{[8.43]^{\star \star \star}}\end{array}$ & $\begin{array}{l}0.448 \\
{[0.31]}\end{array}$ \\
\hline $\begin{array}{l}\text { Capital stock } \\
(\log K)\end{array}$ & $\begin{array}{l}-0.096 \\
{[1.42]}\end{array}$ & $\begin{array}{l}-0.121 \\
{[1.00]}\end{array}$ & $\begin{array}{l}-0.131 \\
{[1.84]^{\star}}\end{array}$ & $\begin{array}{l}-0.242 \\
{[1.19]}\end{array}$ & $\begin{array}{l}-0.039 \\
{[0.39]}\end{array}$ & $\begin{array}{l}-0.01 \\
{[0.06]}\end{array}$ \\
\hline $\log ^{2} N$ & $\begin{array}{l}-0.047 \\
{[2.07]^{\star *}}\end{array}$ & $\begin{array}{l}0.154 \\
{[0.73]}\end{array}$ & $\begin{array}{l}-0.068 \\
{[2.22]^{\star *}}\end{array}$ & $\begin{array}{l}0.164 \\
{[0.65]}\end{array}$ & $\begin{array}{l}-0.034 \\
{[1.01]}\end{array}$ & $\begin{array}{l}0.142 \\
{[0.38]}\end{array}$ \\
\hline $\log ^{2} K$ & 0.021 & 0.016 & 0.016 & 0.016 & 0.023 & 0.013 \\
\hline $\log N \log K$ & $\begin{array}{l}-0.007 \\
{[0.65]}\end{array}$ & $\begin{array}{l}0.007 \\
{[0.27]}\end{array}$ & $\begin{array}{l}0.01 \\
{[0.71]}\end{array}$ & $\begin{array}{l}0.037 \\
{[0.82]}\end{array}$ & $\begin{array}{l}-0.023 \\
{[1.53]}\end{array}$ & $\begin{array}{l}-0.01 \\
{[0.32]}\end{array}$ \\
\hline $\begin{array}{l}\text { Investment in ICT } \\
\text { (dummy: } 1 \text { = yes) }\end{array}$ & $\begin{array}{l}0.144 \\
{[6.66]^{\star \star \star}}\end{array}$ & $\begin{array}{l}0.09 \\
{[2.81]^{\star \star \star}}\end{array}$ & $\begin{array}{l}0.123 \\
{[5.19]^{\star \star \star}}\end{array}$ & $\begin{array}{l}0.049 \\
{[1.34]}\end{array}$ & $\begin{array}{l}0.18 \\
{[4.34]^{\star \star \star}}\end{array}$ & $\begin{array}{l}0.162 \\
{[2.76]^{\star \star \star}}\end{array}$ \\
\hline $\begin{array}{l}\text { State of technology } \\
\text { (index: } 1=\text { up-to- } \\
\text { date; } 5=\text { very old) }\end{array}$ & $\begin{array}{l}-0.11 \\
{[7.28]^{\star \star \star}}\end{array}$ & $\begin{array}{l}-0.093 \\
{[4.07]^{\star \star \star}}\end{array}$ & $\begin{array}{l}-0.105 \\
{[6.19]^{\star * *}}\end{array}$ & $\begin{array}{l}-0.091 \\
{[3.39]^{\star * *}}\end{array}$ & $\begin{array}{l}-0.107 \\
{[3.89]^{\star \star \star}}\end{array}$ & $\begin{array}{l}-0.092 \\
{[2.20]^{* *}}\end{array}$ \\
\hline $\begin{array}{l}\text { Part-time workers } \\
\text { (percentage) }\end{array}$ & $\begin{array}{l}-0.904 \\
{[9.39]^{* \star *}}\end{array}$ & $\begin{array}{l}-0.963 \\
{[6.46]^{\star \star *}}\end{array}$ & $\begin{array}{l}-1.596 \\
{[11.59]^{* * *}}\end{array}$ & $\begin{array}{l}-1.769 \\
{[6.02]^{* * *}}\end{array}$ & $\begin{array}{l}-0.557 \\
{[4.58]^{\star * *}}\end{array}$ & $\begin{array}{l}-0.812 \\
{[4.78]^{* * *}}\end{array}$ \\
\hline $\begin{array}{l}\text { Apprentices } \\
\text { (percentage) }\end{array}$ & $\begin{array}{l}-0.759 \\
{[5.48]^{\star \star \star}}\end{array}$ & $\begin{array}{l}-0.732 \\
{[2.80]^{\star \star \star}}\end{array}$ & $\begin{array}{l}-0.939 \\
{[6.18]^{\star \star \star}}\end{array}$ & $\begin{array}{l}-1.12 \\
{[3.69]^{\star \star \star}}\end{array}$ & $\begin{array}{l}-0.418 \\
{[1.55]}\end{array}$ & $\begin{array}{l}-0.086 \\
{[0.17]}\end{array}$ \\
\hline $\begin{array}{l}\text { Skilled workers } \\
\text { (percentage) }\end{array}$ & $\begin{array}{l}0.253 \\
{[4.99]^{\star \star \star}}\end{array}$ & $\begin{array}{l}0.295 \\
{[3.64]^{\star \star *}}\end{array}$ & $\begin{array}{l}0.214 \\
{[3.40]^{\star * *}}\end{array}$ & $\begin{array}{l}0.331 \\
{[2.77]^{\star \star \star}}\end{array}$ & $\begin{array}{l}0.235 \\
{[2.81]^{\star \star \star}}\end{array}$ & $\begin{array}{l}0.264 \\
{[2.34]^{\star *}}\end{array}$ \\
\hline $\begin{array}{l}\text { Collective } \\
\text { agreement } \\
\text { (dummy: } 1=\text { yes) }\end{array}$ & $\begin{array}{l}0.062 \\
{[2.42]^{\star \star}}\end{array}$ & $\begin{array}{l}0.068 \\
{[1.80]^{*}}\end{array}$ & $\begin{array}{l}0.046 \\
{[1.73]^{\star}}\end{array}$ & $\begin{array}{l}0.061 \\
{[1.36]}\end{array}$ & $\begin{array}{l}0.086 \\
{[1.67]^{\star}}\end{array}$ & $\begin{array}{l}0.08 \\
{[1.16]}\end{array}$ \\
\hline Constant & $\begin{array}{l}11.685 \\
{[39.25]^{\text {***}}}\end{array}$ & $\begin{array}{l}13.933 \\
{[8.14]^{\star * *}}\end{array}$ & $\begin{array}{l}12.052 \\
{[39.49]^{\star * *}}\end{array}$ & $\begin{array}{l}15.448 \\
{[7.12]^{\star * *}}\end{array}$ & $\begin{array}{l}11.937 \\
{[24.23]^{\star * *}}\end{array}$ & $\begin{array}{l}13.144 \\
{[4.30]^{\star \star *}}\end{array}$ \\
\hline $\begin{array}{l}\text { Output elasticities } \\
\text { at sample means }\end{array}$ & & & & & & \\
\hline$\varepsilon_{Y N}$ & 0.881 & 0.900 & 0.941 & 0.904 & 0.793 & 0.860 \\
\hline$p$-value & {$[0.000]$} & {$[0.000]$} & {$[0.000]$} & {$[0.000]$} & {$[0.000]$} & 0.000 \\
\hline$\varepsilon_{Y K}$ & 0.118 & 0.091 & 0.095 & 0.082 & 0.142 & 0.104 \\
\hline$p$-value & {$[0.000]$} & {$[0.000]$} & {$[0.000]$} & [0.000] & {$[0.000]$} & 0.000 \\
\hline No. of observations & 5622 & 1949 & 3523 & 1198 & 2099 & 751 \\
\hline No. of plants & 2564 & 895 & 1696 & 593 & 868 & 302 \\
\hline $\mathrm{R}^{2}$ & 0.87 & 0.64 & 0.90 & 0.58 & 0.82 & 0.71 \\
\hline
\end{tabular}

Notes: Regressions also include sector and year dummies.

${ }^{* * *},{ }^{* *},{ }^{*}$ denote significance at the $.01, .05$, and .10 levels, respectively. 
Table 5: Works Council Effects on Productivity from OLS Regressions of a Translog Production Function, Individual Years

\begin{tabular}{|c|c|c|c|c|c|c|c|}
\hline & & & 1997 & 1998 & 1999 & 2000 & Pooled \\
\hline & & $N \geq 5$ & 0.259 & 0.235 & 0.207 & 0.238 & 0.232 \\
\hline & & & {$[5.76]^{\star \star *}$} & {$[5.92]^{\star * *}$} & {$[5.82]^{\star \star \star}$} & {$[7.35]^{\star \star *}$} & {$[8.88]^{\star \star *}$} \\
\hline & Total & & 2024 & 2520 & 2969 & 3952 & 11465 \\
\hline & Total & $100 \geq N \geq 21$ & 0.123 & 0.107 & 0.056 & 0.172 & 0.118 \\
\hline & & & {$[1.86]^{*}$} & {$[1.94]^{\star}$} & [1.16] & {$[3.60]^{\star \star \star}$} & {$[3.22]^{\star * *}$} \\
\hline & & & 546 & 734 & 942 & 1373 & 3595 \\
\hline & & $N \geq 5$ & 0.305 & 0.172 & 0.131 & 0.161 & 0.177 \\
\hline & & & {$[5.31]^{\star * *}$} & {$[3.55]^{\star \star *}$} & {$[3.31]^{\star * *}$} & {$[4.05]^{\star \star *}$} & {$[5.71]^{\star \star *}$} \\
\hline Germanv & Manu- & & 1204 & 1497 & 1807 & 2362 & 6870 \\
\hline Mentianty & facturing & $100 \geq N \geq 21$ & 0.119 & 0.063 & -0.011 & 0.07 & 0.046 \\
\hline & & & {$[1.73]^{*}$} & [0.94] & {$[-0.18]$} & [1.22] & [1.03] \\
\hline & & & 291 & 394 & 549 & 753 & 1987 \\
\hline & & $N \geq 5$ & 0.212 & 0.283 & 0.288 & 0.291 & 0.275 \\
\hline & & & {$[2.88]^{\star * *}$} & {$[4.46]^{\star \star *}$} & {$[4.60]^{\star * \star}$} & {$[5.56]^{\star * *}$} & {$[6.31]^{\star * *}$} \\
\hline & Services & & 820 & 1023 & 1162 & 1590 & 4595 \\
\hline & services & $100 \geq N \geq 21$ & 0.098 & 0.145 & 0.139 & 0.269 & 0.183 \\
\hline & & & [0.82] & [1.61] & {$[1.75]^{*}$} & {$[3.41]^{\star \star \star}$} & {$[3.05]^{\star \star *}$} \\
\hline & & & 255 & 340 & 393 & 620 & 1608 \\
\hline & & $N \geq 5$ & 0.2 & 0.133 & 0.227 & 0.229 & 0.206 \\
\hline & & & {$[2.83]^{\star \star *}$} & {$[2.02]^{\star \star}$} & {$[3.69]^{\star \star *}$} & {$[5.15]^{\star * *}$} & {$[5.21]^{\star * *}$} \\
\hline & Total & & 1003 & 1234 & 1373 & 2233 & 5843 \\
\hline & & $100 \geq N \geq 21$ & 0.083 & -0.039 & 0.074 & 0.177 & 0.098 \\
\hline & & & {$[0.79]$} & {$[-0.43]$} & [0.83] & {$[2.64]^{\star \star \star}$} & {$[1.80]^{*}$} \\
\hline & & & 227 & 310 & 367 & 742 & 1646 \\
\hline & & $N \geq 5$ & 0.242 & 0.049 & 0.101 & 0.102 & 0.113 \\
\hline & & & {$[3.16]^{\star \star *}$} & [0.73] & [1.52] & {$[1.89]^{\star}$} & {$[2.59]^{\star \star \star}$} \\
\hline western & Manu- & & 615 & 727 & 805 & 1200 & 3347 \\
\hline Germany & facturing & $100 \geq N \geq 21$ & 0.073 & -0.055 & -0.111 & -0.038 & -0.042 \\
\hline & & & [0.58] & {$[-0.54]$} & {$[-1.06]$} & {$[-0.47]$} & {$[-0.71]$} \\
\hline & & & 116 & 155 & 190 & 328 & 789 \\
\hline & & $N \geq 5$ & 0.191 & 0.203 & 0.32 & 0.306 & 0.27 \\
\hline & & & {$[1.68]^{\star}$} & {$[1.82]^{*}$} & {$[3.03]^{\star \star *}$} & {$[4.45]^{\star \star \star}$} & {$[4.14]^{\star \star *}$} \\
\hline & Services & & 388 & 507 & 568 & 1033 & 2496 \\
\hline & SeIvices & $100 \geq N \geq 21$ & 0.076 & -0.075 & 0.215 & 0.311 & 0.186 \\
\hline & & & [0.37] & {$[-0.45]$} & [1.39] & {$[3.05]^{* * *}$} & {$[2.04]^{\star \star}$} \\
\hline & & & 111 & 155 & 177 & 414 & 857 \\
\hline & & $N \geq 5$ & 0.305 & 0.304 & 0.202 & 0.277 & 0.266 \\
\hline & & & {$[5.13]^{\star * *}$} & {$[6.18]^{\star * *}$} & {$[4.83]^{\star * *}$} & {$[5.90]^{* * *}$} & {$[7.77]^{\star * *}$} \\
\hline & Total & & 1021 & & 1596 & 1719 & 5622 \\
\hline & rotal & $100 \geq N \geq 21$ & 0.17 & 0.198 & 0.047 & 0.171 & 0.137 \\
\hline & & & {$[1.88]^{*}$} & {$[2.75]^{\star \star *}$} & {$[0.81]$} & {$[2.54]^{\star *}$} & {$[2.84]^{* * *}$} \\
\hline & & & 319 & 424 & 575 & 631 & 1949 \\
\hline & & $N \geq 5$ & 0.338 & 0.234 & 0.149 & 0.233 & 0.222 \\
\hline & & & {$[4.43]^{\star \star *}$} & {$[3.62]^{\star \star \star}$} & {$[2.96]^{\star \star *}$} & {$[3.93]^{\star \star *}$} & {$[5.25]^{\star \star *}$} \\
\hline eastern & Manu- & & 589 & 770 & 1002 & 1162 & 3523 \\
\hline Germany & facturing & $100 \geq N \geq 21$ & 0.164 & 0.142 & 0.038 & 0.184 & 0.111 \\
\hline & & & {$[1.89]^{*}$} & {$[1.69]^{*}$} & [0.52] & {$[2.21]^{\star *}$} & {$[1.85]^{*}$} \\
\hline & & & 175 & 239 & 359 & 425 & 1198 \\
\hline & & $N \geq 5$ & 0.253 & 0.361 & 0.241 & 0.3 & 0.294 \\
\hline & & & {$[2.54]^{\star \star}$} & {$[4.76]^{\star \star \star}$} & {$[3.38]^{\star \star \star}$} & {$[3.93]^{\star \star \star}$} & {$[5.17]^{\star \star \star}$} \\
\hline & & & 432 & 516 & 594 & 557 & 2099 \\
\hline & services & $100 \geq N \geq 21$ & 0.11 & 0.242 & 0.072 & 0.13 & 0.154 \\
\hline & & & {$[0.61]$} & {$[2.09]^{\star *}$} & [0.80] & [1.12] & {$[1.98]^{\star *}$} \\
\hline & & & 144 & 185 & 216 & 206 & 751 \\
\hline
\end{tabular}

Notes: Each cell is from a separate regression. The cell entries give coefficient estimate, $t$-value, and number of observations in the regression. Dependent variable and explanatory variables as in Tables 2 through 4. 
Table 6: Production Frontier Estimates of the Technical Efficiency Estimates of Plants with and without a Works Council (WC),1997-2000

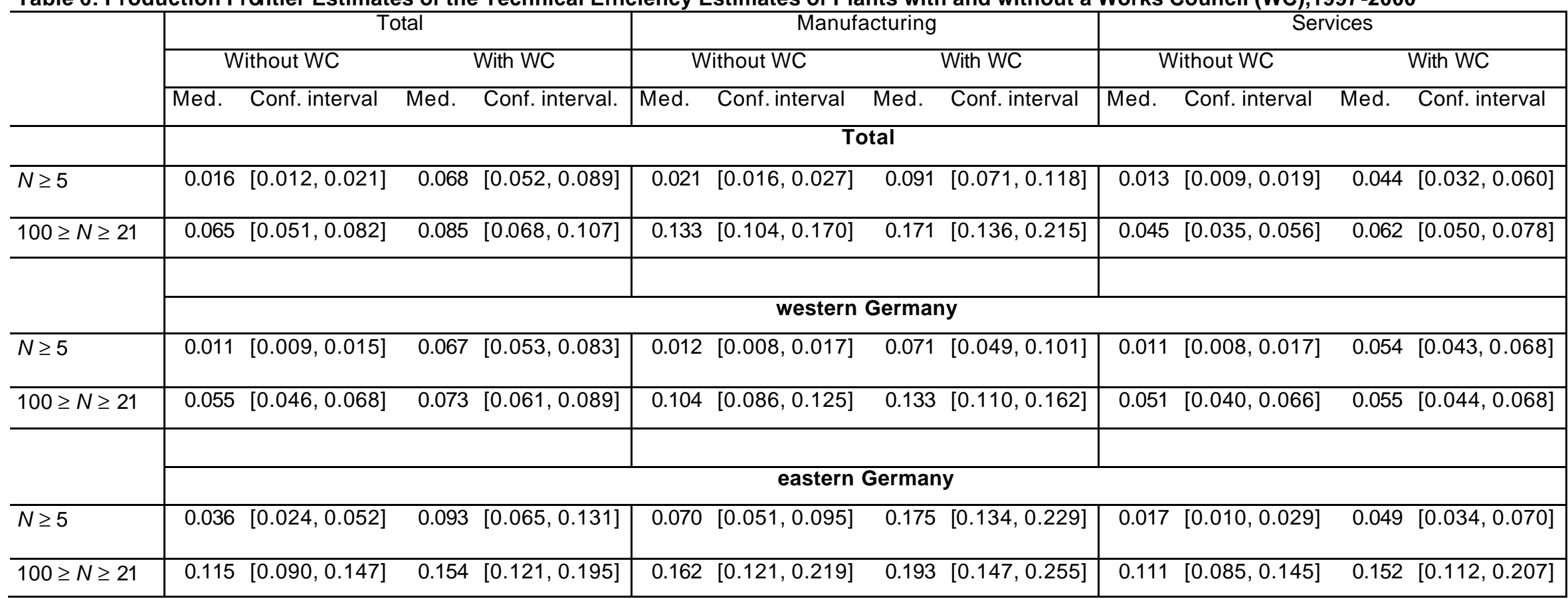

Notes: The production frontier estimation is fixed effects, with log total sales as the dependent variable.

The estimates control for industry effects. Confidence intervals are for the .95 level. 
Table 7: OLS Regressions of a Cobb-Douglas Production Function in Differences, 1997- 2000 (dependent variable: $\Delta$ log total sales)

\begin{tabular}{|c|c|c|c|c|c|c|}
\hline 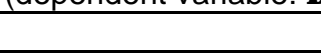 & \multicolumn{2}{|l|}{ Total } & \multicolumn{2}{|c|}{ Western Germany } & \multicolumn{2}{|c|}{ Eastern Germany } \\
\hline & $N \geq 5$ & $100 \geq N \geq 21$ & $N \geq 5$ & $100 \geq N \geq 21$ & $N \geq 5$ & $100 \geq N \geq 21$ \\
\hline & (1) & (2) & (3) & (4) & (5) & (6) \\
\hline $\begin{array}{l}\text { Works council } \\
\text { (dummy) }\end{array}$ & & & & & & \\
\hline 1997:yes; 2000:yes & $\begin{array}{l}0.013 \\
{[0.45]}\end{array}$ & $\begin{array}{l}-0.012 \\
{[0.26]}\end{array}$ & $\begin{array}{l}0.051 \\
{[1.38]}\end{array}$ & $\begin{array}{l}-0.004 \\
{[0.07]}\end{array}$ & $\begin{array}{l}-0.009 \\
{[0.20]}\end{array}$ & $\begin{array}{l}0.016 \\
{[0.22]}\end{array}$ \\
\hline 1997:no; 2000:yes & $\begin{array}{l}0.02 \\
{[0.21]}\end{array}$ & $\begin{array}{l}0.143 \\
{[1.40]}\end{array}$ & $\begin{array}{l}0.069 \\
{[0.54]}\end{array}$ & $\begin{array}{l}-0.007 \\
{[0.07]}\end{array}$ & $\begin{array}{l}0.019 \\
{[0.13]}\end{array}$ & $\begin{array}{l}0.242 \\
{[1.40]}\end{array}$ \\
\hline 1997:yes; 2000:no & $\begin{array}{l}0.159 \\
{[1.53]}\end{array}$ & $\begin{array}{l}-0.059 \\
{[0.70]}\end{array}$ & $\begin{array}{l}0.041 \\
{[0.66]}\end{array}$ & $\begin{array}{l}0.219 \\
{[2.78]^{\star \star \star}}\end{array}$ & $\begin{array}{l}0.202 \\
{[1.22]}\end{array}$ & $\begin{array}{l}-0.145 \\
{[1.42]}\end{array}$ \\
\hline $\begin{array}{l}\text { Number of } \\
\text { employees } \\
(\Delta \log N)\end{array}$ & $\begin{array}{l}0.622 \\
{[7.09]^{\star * *}}\end{array}$ & $\begin{array}{l}0.536 \\
{[5.72]^{\star \star \star}}\end{array}$ & $\begin{array}{l}0.529 \\
{[4.52]^{\star \star \star}}\end{array}$ & $\begin{array}{l}0.306 \\
{[1.83]^{\star}}\end{array}$ & $\begin{array}{l}0.686 \\
{[6.06]^{\star \star *}}\end{array}$ & $\begin{array}{l}0.607 \\
{[4.87]^{\star \star *}}\end{array}$ \\
\hline $\begin{array}{l}\text { Capital stock } \\
(\Delta \log K)\end{array}$ & $\begin{array}{l}0.014 \\
{[0.99]}\end{array}$ & $\begin{array}{l}0.082 \\
{[4.08]^{\star \star \star}}\end{array}$ & $\begin{array}{l}0.014 \\
{[0.46]}\end{array}$ & $\begin{array}{l}0.082 \\
{[1.43]}\end{array}$ & $\begin{array}{l}0.016 \\
{[0.84]}\end{array}$ & $\begin{array}{l}0.085 \\
{[3.71]^{\star \star *}}\end{array}$ \\
\hline $\begin{array}{l}\text { Investment in ICT (4- } \\
\text { year-average of } \\
\text { dummy) }\end{array}$ & $\begin{array}{l}0.054 \\
{[1.31]}\end{array}$ & $\begin{array}{l}0.05 \\
{[0.76]}\end{array}$ & $\begin{array}{l}0.042 \\
{[0.79]}\end{array}$ & $\begin{array}{l}-0.017 \\
{[0.19]}\end{array}$ & $\begin{array}{l}0.049 \\
{[0.79]}\end{array}$ & $\begin{array}{l}0.041 \\
{[0.42]}\end{array}$ \\
\hline $\begin{array}{l}\text { State of technology } \\
\text { (4-year-average of } \\
\text { index) }\end{array}$ & $\begin{array}{l}-0.001 \\
{[0.02]}\end{array}$ & $\begin{array}{l}0.019 \\
{[0.64]}\end{array}$ & $\begin{array}{l}-0.05 \\
{[2.25]^{\star \star}}\end{array}$ & $\begin{array}{l}0.006 \\
{[0.15]}\end{array}$ & $\begin{array}{l}0.033 \\
{[0.82]}\end{array}$ & $\begin{array}{l}0.018 \\
{[0.38]}\end{array}$ \\
\hline $\begin{array}{l}\text { Part-time workers } \\
(\Delta \text { percentage })\end{array}$ & $\begin{array}{l}0.136 \\
{[0.64]}\end{array}$ & $\begin{array}{l}-0.147 \\
{[0.95]}\end{array}$ & $\begin{array}{l}0.037 \\
{[0.28]}\end{array}$ & $\begin{array}{l}0.283 \\
{[1.08]}\end{array}$ & $\begin{array}{l}0.272 \\
{[0.67]}\end{array}$ & $\begin{array}{l}-0.533 \\
{[2.23]^{\star *}}\end{array}$ \\
\hline $\begin{array}{l}\text { Apprentices } \\
(\Delta \text { percentage })\end{array}$ & $\begin{array}{l}-0.191 \\
{[0.66]}\end{array}$ & $\begin{array}{l}-0.426 \\
{[1.12]}\end{array}$ & $\begin{array}{l}-0.325 \\
{[0.72]}\end{array}$ & $\begin{array}{l}0.057 \\
{[0.09]}\end{array}$ & $\begin{array}{l}-0.177 \\
{[0.46]}\end{array}$ & $\begin{array}{l}-0.597 \\
{[1.11]}\end{array}$ \\
\hline $\begin{array}{l}\text { Skilled workers } \\
(\Delta \text { percentage) }\end{array}$ & $\begin{array}{l}0.06 \\
{[0.71]}\end{array}$ & $\begin{array}{l}0.073 \\
{[1.19]}\end{array}$ & $\begin{array}{l}0.09 \\
{[1.44]}\end{array}$ & $\begin{array}{l}0.15 \\
{[1.66]^{*}}\end{array}$ & $\begin{array}{l}0.08 \\
{[0.53]}\end{array}$ & $\begin{array}{l}0.061 \\
{[0.67]}\end{array}$ \\
\hline $\begin{array}{l}\text { Collective } \\
\text { agreement (dummy) }\end{array}$ & & & & & & \\
\hline 1997:yes; 2000:yes & $\begin{array}{l}0.001 \\
{[0.02]}\end{array}$ & $\begin{array}{l}-0.059 \\
{[1.16]}\end{array}$ & $\begin{array}{l}-0.068 \\
{[1.27]}\end{array}$ & $\begin{array}{l}-0.212 \\
{[2.68]^{\star \star \star}}\end{array}$ & $\begin{array}{l}0.042 \\
{[0.90]}\end{array}$ & $\begin{array}{l}-0.012 \\
{[0.17]}\end{array}$ \\
\hline 1997:no; 2000:yes & $\begin{array}{l}-0.061 \\
{[0.86]}\end{array}$ & $\begin{array}{l}-0.224 \\
{[1.97]^{\star \star}}\end{array}$ & $\begin{array}{l}-0.094 \\
{[0.80]}\end{array}$ & $\begin{array}{l}0.004 \\
{[0.02]}\end{array}$ & $\begin{array}{l}-0.032 \\
{[0.36]}\end{array}$ & $\begin{array}{l}-0.271 \\
{[2.07]^{* *}}\end{array}$ \\
\hline 1997:yes; 2000:no & $\begin{array}{l}0.028 \\
{[0.57]}\end{array}$ & $\begin{array}{l}0.047 \\
{[0.84]}\end{array}$ & $\begin{array}{l}-0.075 \\
{[1.01]}\end{array}$ & $\begin{array}{l}-0.072 \\
{[0.73]}\end{array}$ & $\begin{array}{l}0.061 \\
{[0.96]}\end{array}$ & $\begin{array}{l}0.102 \\
{[1.37]}\end{array}$ \\
\hline $\begin{array}{l}\text { Dummy eastern } \\
\text { Germany }\end{array}$ & $\begin{array}{l}-0.066 \\
{[2.66]^{\star * *}}\end{array}$ & $\begin{array}{l}-0.057 \\
{[1.55]}\end{array}$ & & & & \\
\hline Constant & $\begin{array}{l}-0.232 \\
{[1.16]}\end{array}$ & $\begin{array}{l}-0.828 \\
{[6.09]^{\star * *}}\end{array}$ & $\begin{array}{l}-0.269 \\
{[2.78]^{\star * *}}\end{array}$ & $\begin{array}{l}0.113 \\
{[0.80]}\end{array}$ & $\begin{array}{l}-0.33 \\
{[1.32]}\end{array}$ & $\begin{array}{l}-0.803 \\
{[4.70]^{\star * *}}\end{array}$ \\
\hline $\begin{array}{l}\text { No. of observations } \\
\mathrm{R}^{2}\end{array}$ & $\begin{array}{l}1098 \\
0.31\end{array}$ & $\begin{array}{l}314 \\
0.37\end{array}$ & $\begin{array}{l}506 \\
0.3\end{array}$ & $\begin{array}{l}126 \\
0.42\end{array}$ & $\begin{array}{l}592 \\
0.35\end{array}$ & $\begin{array}{l}188 \\
0.44\end{array}$ \\
\hline
\end{tabular}

Notes: $\Delta$ denotes the difference between 2000 and 1997 of the respective variable. The regressions also include sector dummies. ${ }^{* * *},{ }^{* *},{ }^{*}$ denote significance at the $.01 . .05$, and .10 levels, respectively. 


\section{Endnotes}

${ }^{1}$ An English-language summary of the report can be downloaded at www.mpi-fgkoeln.mpg.de/endbericht/inhalt_e.html.

${ }^{2}$ Other supportive theoretical arguments reflect agency considerations. Thus, either institution - union or works council - can be construed as a more efficient monitor of managers than the shareholder principal (see, respectively, Kuhn, 1985, and Jirjahn, 2002). That said, such approaches still confront a bargaining problem.

${ }^{3}$ This is not the place to provide chapter and verse on the powers of the works council (but see Müller-Jentsch, 1995; Addison, Bellmann, Schnabel, and Wagner 2003). Suffice it to say here that the information and consultation rights are not merely extensive but are also increasing in establishment size. To take just one example from information disclosure: in plants with more than 100 employees an economic committee has to be set up. This standing body is appointed by the works council, and has to be informed by the employer on the current and future economic situation of the firm and be given all relevant and financial information. The more important codetermination rights of the council cover the commencement and termination of working hours, the regulation of overtime and reduced working hours, leave arrangements, the introduction of technical devices to monitor employee performance, and remuneration arrangements including the fixing of job and bonus rates and other forms of performance relate d pay. (Under the recent changes in the law, works councils may now initiate and codetermine vocational training measures in respect of employees whose qualifications are likely to be rendered obsolete, and have new codetermination rights in the operation of teamworking.) In plants with more than 20 employees, the consent rights of the works council cover the engagement, grading/regrading, and transfer of workers as well as individual dismissals.

${ }^{4}$ When assuming that the translog exactly represents the underlying production process, tests on the separability of factor inputs become more restrictive (see Denny and Fuss, 1977). But separability is not an issue in the present study.

${ }^{5}$ We consider the results as only informed guesstimates for two reasons. First, almost two thirds of the observations are in multiples of 5 per cent, implying measurement error. Second, the reported share of material costs changes on average by 11.6 per cent in any two years, which is unrealistically high.

${ }^{6}$ Using pooled data for 1997 to 2000, the correlation coefficients for the all-establishment sample and for manufacturing and services are 0.942, 0.962, and 0.891, respectively. The corresponding values for western (eastern) Germany are $0.950(0.918), .970(0.937)$, and .900 (0.875).

7 Information on establishments that were not panel accessions in 1999 was already interpolated by the IAB, based on information in 1998 .

${ }^{8}$ Stata/SE 7.0 was used to estimate the empirical models, using the cluster(establishment) option because observations are considered to be independent across but not necessarily within establishments. For the estimation of the variance-covariance matrix of the coefficient vector the Huber/White estimator was used. 
${ }^{9}$ Having obtained technical efficiencies for each plant according to equations (6) and (7), we eliminated those plants that were in the top and the bottom percentile of the efficiency distribution and repeated the analysis. This should ensure that our results are not contaminated by outliers. Furthermore, since it would not make much sense to draw conclusions about technical efficiency from plants that only make one appearance in the regression sample, we report the technical efficiency and its confidence interval of the plant that is observed four times and which is closest to the median. Although this procedure had little effect on measured efficiency it did affect the reported confidence intervals.

${ }^{10}$ In its official estimates of the capital stock, the German Federal Statistical Office uses depreciation periods of six and thirteen years (see Schmalwasser, 2001). As a sensitivity analysis, we repeated our calculations using the thirteen year rule. The results were scarcely affected and we therefore report (and discuss) estimates based on a six year depreciation cycle alone.

${ }^{11}$ All computations were performed at the Institute for Employment Research of the Federal Labor Service, using Stata/SE 7.0. To facilitate replication and extensions the do-files are available from thorsten.schank@wiso.uni-erlangen.de.

12 The estimated coefficient $\beta$ of the works council dummy has to be transformed using the formula $100\left(\mathrm{e}^{\beta}-1\right)$ to obtain the percentage change in the endogenous variable.

13 This is evident from equation (3) in section IV. If $\beta_{11}$ and $\beta_{12}$ are negative (and employment and capital are positively correlated), the output elasticity with respect to employment rises if employment increases.

${ }^{14}$ Interestingly, Frick (2002) reports similar works council effects without questioning their magnitude.

${ }^{15}$ It is not clear to us why the impact of works councils on productivity should be stronger for the service sector.

${ }^{16}$ Note that we can not further disaggregate by manufacturing and services for the two broad regions on this occasion due to the small number of cases.

${ }^{17}$ The only exception is establishments with 21 to 100 employees that had a works council in 1997 but not in 2000, and which according to the highly statistically significant point estimate reported in Table 7 had a rate of change in productivity 25 per cent above that of firms without a works council in both years. However, as a practical matter, this particular 'group' of switchers comprises a single establishment. 


\section{IZA Discussion Papers}

\begin{tabular}{|c|c|c|c|c|}
\hline No. & Author(s) & Title & Area & Date \\
\hline 798 & $\begin{array}{l}\text { J. J. Heckman } \\
\text { J. A. Smith }\end{array}$ & $\begin{array}{l}\text { The Determinants of Participation in a Social } \\
\text { Program: Evidence from a Prototypical Job } \\
\text { Training Program }\end{array}$ & 6 & $06 / 03$ \\
\hline 799 & R. A. Hart & $\begin{array}{l}\text { General Human Capital and Employment } \\
\text { Adjustment in the Great Depression: } \\
\text { Apprentices and Journeymen in UK Engineering }\end{array}$ & 2 & $06 / 03$ \\
\hline 800 & $\begin{array}{l}\text { T. Beissinger } \\
\text { C. Knoppik }\end{array}$ & $\begin{array}{l}\text { Sind Nominallöhne starr? Neuere Evidenz und } \\
\text { wirtschaftspolitische Implikationen }\end{array}$ & 7 & $06 / 03$ \\
\hline 801 & A. Launov & $\begin{array}{l}\text { A Study of the Austrian Labor Market Dynamics } \\
\text { Using a Model of Search Equilibrium }\end{array}$ & 2 & $06 / 03$ \\
\hline 802 & $\begin{array}{l}\text { H. Antecol } \\
\text { P. Kuhn } \\
\text { S. J. Trejo }\end{array}$ & $\begin{array}{l}\text { Assimilation via Prices or Quantities? Labor } \\
\text { Market Institutions and Immigrant Earnings } \\
\text { Growth in Australia, Canada, and the United } \\
\text { States }\end{array}$ & 1 & $06 / 03$ \\
\hline 803 & R. Lalive & Social Interactions in Unemployment & 3 & $06 / 03$ \\
\hline 804 & J. H. Abbring & Dynamic Econometric Program Evaluation & 6 & $06 / 03$ \\
\hline 805 & $\begin{array}{l}\text { G. J. van den Berg } \\
\text { A. van Vuuren }\end{array}$ & The Effect of Search Frictions on Wages & 6 & $06 / 03$ \\
\hline 806 & G. J. van den Berg & $\begin{array}{l}\text { Multiple Equilibria and Minimum Wages in Labor } \\
\text { Markets with Informational Frictions and } \\
\text { Heterogeneous Production Technologies }\end{array}$ & 6 & $06 / 03$ \\
\hline 807 & $\begin{array}{l}\text { P. Frijters } \\
\text { M. A. Shields } \\
\text { N. Theodoropoulos } \\
\text { S. Wheatley Price }\end{array}$ & $\begin{array}{l}\text { Testing for Employee Discrimination Using } \\
\text { Matched Employer-Employee Data: } \\
\text { Theory and Evidence }\end{array}$ & 5 & $06 / 03$ \\
\hline 808 & $\begin{array}{l}\text { F. Docquier } \\
\text { H. Rapoport }\end{array}$ & $\begin{array}{l}\text { Remittances and Inequality: A Dynamic } \\
\text { Migration Model }\end{array}$ & 1 & $06 / 03$ \\
\hline 809 & $\begin{array}{l}\text { S. Commander } \\
\text { M. Kangasniemi } \\
\text { L. A. Winters }\end{array}$ & The Brain Drain: Curse or Boon? & 1 & $06 / 03$ \\
\hline 810 & $\begin{array}{l}\text { J. H. Abbring } \\
\text { G. J. van den Berg }\end{array}$ & $\begin{array}{l}\text { A Simple Procedure for the Evaluation of } \\
\text { Treatment Effects on Duration Variables }\end{array}$ & 6 & $06 / 03$ \\
\hline 811 & $\begin{array}{l}\text { M. Corak } \\
\text { W.-H. Chen }\end{array}$ & $\begin{array}{l}\text { Firms, Industries, and Unemployment Insurance: } \\
\text { An Analysis Using Employer-Employee Data }\end{array}$ & 1 & $06 / 03$ \\
\hline 812 & $\begin{array}{l}\text { J. T. Addison } \\
\text { T. Schank } \\
\text { C. Schnabel } \\
\text { J. Wagner }\end{array}$ & $\begin{array}{l}\text { German Works Councils in the Production } \\
\text { Process }\end{array}$ & 3 & $06 / 03$ \\
\hline
\end{tabular}

An updated list of IZA Discussion Papers is available on the center's homepage www.iza.org. 